\title{
Stable isotope analysis indicates resource partitioning and trophic niche overlap in larvae of four tuna species in the Gulf of Mexico
}

\author{
Raúl Laiz-Carrión ${ }^{1, *}$, Trika Gerard ${ }^{2,3}$, Justin J. Suca ${ }^{4}$, Estrella Malca ${ }^{2,5}$, \\ Amaya Uriarte ${ }^{1}$, José M. Quintanilla ${ }^{1}$, Sarah Privoznik ${ }^{2,5}$, Joel K. Llopiz ${ }^{4}$, \\ John Lamkin ${ }^{2}$, Alberto García ${ }^{1}$ \\ ${ }^{1}$ Instituto Español de Oceanografía, Centro Oceanográfico de Málaga, Fuengirola, Málaga, Puerto Pesquero s/n. 29640, Spain \\ ${ }^{2}$ NOAA National Marine Fisheries Service, Southeast Fisheries Science Center, 75 Virginia Beach Drive, Miami, FL 33149, USA \\ ${ }^{3}$ University of Phoenix, South Florida Campus, 2400 SW 145 Ave, Miramar, FL 33027, USA \\ ${ }^{4}$ Biology Department, Woods Hole Oceanographic Institution, 266 Woods Hole Rd MS\#33, Woods Hole, MA 02543, USA \\ ${ }^{5}$ Cooperative Institute for Marine and Atmospheric Studies, University of Miami, 4600 Rickenbacker Causeway, Miami, \\ FL 33149, USA
}

\begin{abstract}
In this study we assessed the trophic ecology of bluefin tuna Thunnus thynnus larvae from the Gulf of Mexico, together with the co-occurring larvae of blackfin tuna T. atlanticus, bullet tuna Auxis rochei, and skipjack Katsuwonus pelamis, using both bulk-tissue stable isotope analysis $\left(\mathrm{SIA}_{\text {bulk }}\right)$ and compound-specific analysis of amino acids $\left(\mathrm{CSIA}_{\mathrm{AA}}\right)$. Bulk nitrogen $\left(\delta^{15} \mathrm{~N}_{\text {bulk }}\right)$ and carbon $\left(\delta^{13} C_{\text {bulk }}\right)$ values differed significantly among species, suggesting partitioning of resources due to an adaptive process allowing these tunas to share the ecosystem's trophic resources during this early life period. K. pelamis had the largest isotopic niche width, likely due to piscivorous feeding at an earlier age compared to the other species, with an isotopic niche overlap of $17.5 \%$ with $T$. thynnus, $15.8 \%$ with $T$. atlanticus, and $31.2 \%$ with $A$. rochei. This trophic overlap suggests a mix of competition and trophic differentiation among these 4 species of tuna larvae. Higher nitrogen isotopic signatures in preflexion versus postflexion larvae of $T$. thynnus measured using both SIA $_{\text {bulk }}$ and CSIA $_{\mathrm{AA}}$ indicate maternal isotopic transmission, as well as 'capital breeder'-like characteristics. In contrast, the nitrogen isotopic ratios of the other 3 species were similar between ontogenetic stages. These observations suggest different breeding strategies within the study area for T. atlanticus, K. pelamis, and A. rochei compared to T. thynnus. No significant differences were observed among the 4 species' trophic positions (TPs) estimated by CSIA $_{\mathrm{AA}}$, whereas a higher

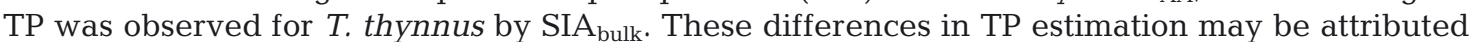
to discrepancies in baseline estimates.
\end{abstract}

KEY WORDS: Trophic ecology · Bluefin · Blackfin · Bullet $\cdot$ Skipjack · Tuna larvae $\cdot$ Stable isotope $\cdot$ CSIA $\cdot$ Trophic ecology $\cdot$ Isotopic niche $\cdot$ Breeding strategies

\section{INTRODUCTION}

Tunas (family Scombridae) are epipelagic marine fishes that support lucrative commercial and recreational fisheries throughout tropical and temper-

*Corresponding author: raul.laiz@ieo.es ate waters of the world (Block \& Stevens 2001). The tropical tunas Katsuwonus pelamis (skipjack) and Auxis rochei (bullet tuna) are found in warm equatorial ecosystems, while Thunnus thynnus (Atlantic bluefin tuna) is a temperate species (Fromentin \& 
Fonteneau 2001). The tropical-temperate tunas, including $T$. atlanticus (blackfin tuna), utilize mixed water masses for feeding and spawning (Teo \& Block 2010, Muhling et al. 2017, Cornic \& Rooker 2018). Tagging studies have provided evidence that $T$. thynnus is highly migratory (Lutcavage et al. 1999, Block et al. 2001, Block et al. 2005, De Metrio et al. 2002), traveling long distances depending on their size (Rooker et al. 2007). T. thynnus make extensive migrations from their cold foraging grounds in the North Atlantic, including the Scotian Shelf and Gulf of Maine, to either the Gulf of Mexico (GOM; western stock) or Mediterranean Sea (eastern stock) in order to spawn, with evidence for a high degree of fidelity to natal areas (Rooker et al. 2007, Muhling et al. 2017). Other smaller tuna species, such as skipjack and bullet tuna, are restricted to warm-water environments, and do not migrate to temperate, coldwater habitats as T. thynnus do. Despite their circumglobal distribution, adult foraging and spawning grounds of these species largely overlap (Reglero et al. 2014) and adults of these species are present in the GOM throughout much of the year (Block et al. 2005, Teo \& Block 2010, Rooker et al. 2013). A similar pattern in the spawning grounds has been observed for T. thynnus in the Mediterranean's Balearic Sea where this species concurrently spawns with $A$. rochei and T. alalunga (García et al. 2017). A. rochei spends most of the year in the region (Alemany et al. 2010) while $T$. alalunga forms a genetically distinct Mediterranean population (Davies et al. 2011). Similarly, Luckhurst et al. (2001) observed that T. atlanticus recaptures were near the tagging locations, indicating little migratory movement in the GOM and the Northwest Atlantic.

The GOM is an ecologically important region for each of these 4 tuna species (Block \& Stevens 2001). It is considered the primary spawning ground for the western T. thynnus stock (Richards 1977, Richards \& Potthoff 1980), although larvae of this species have been collected outside the GOM along the Yucatan (Muhling et al. 2011), the Bahamas (Lutcavage et al. 1999, Rooker et al. 2007, Lamkin et al. 2014), and most recently in the Slope Sea (Richardson et al. 2016). During spawning events, T. thynnus adults target distinctive oceanographic conditions in the GOM (e.g. sea surface temperature and mesoscale eddies), suggesting that these habitats promote survival of the early life stages (Bakun \& Broad 2003, Teo \& Block 2010, Bakun 2013, Muhling et al. 2013, 2017). K. pelamis, T. atlanticus, and $A$. rochei also spawn in the GOM over a much longer time period than $T$. thynnus, generally spring through fall (Reglero et al. 2014, Muhling et al. 2017, Cornic et al. 2018), compared to the more restricted spawning season during late spring for T. thynnus (Block et al. 2001, 2005, Teo et al. 2007, Rooker et al. 2007, Reglero et al. 2014, Muhling et al. 2017).

The prodigious swimming capabilities and migratory nature of tunas may allow offspring to be placed in favorable larval habitats, despite the potentially long distances between such regions and those best suited for the feeding and growth of adults (Bakun 1996, Block et al. 2001). The planktonic larval stage of these marine teleosts must survive in potentially food-limited waters (Bakun 2006, Llopiz \& Hobday 2015), where very little is known regarding the primary processes influencing larval survival in oligotrophic spawning grounds.

Feeding ecology of larval tunas using stomach contents has been described globally (Llopiz \& Hobday 2015) and along the Straits of Florida (Llopiz et al. 2010). Larval feeding for T. thynnus has been examined in the Mediterranean Sea (Catalán et al. 2011, Uriarte et al. 2018, 2019) and in the GOM (Llopiz et al. 2015, Tilley et al. 2016), showing a predominant diet of copepods, copepod nauplii, appendicularians, and cladocerans, whereas other tuna larvae such as Auxis spp. and $K$. pelamis show a preference for appendicularians (Llopiz et al. 2010, Llopiz \& Hobday 2015). Appendicularians are an essential part of the larval tuna diet in the Pacific Ocean as well, functioning as a trophic link from ichthyoplankton to the microbial loop (Nakagawa et al. 2007, Kodama et al. 2017).

However, stomach content analysis only reflects a 'snapshot' of an individual's recently ingested prey and can be highly variable, requiring large sample sizes to statistically examine differences among species, regions, and/or time periods (Polis \& Strong 1996, Pinnegar \& Polunin 1999). Accordingly, the use of stable isotopes has become a widespread complementary method to stomach content analysis to elucidate diets and characterize trophic interactions in marine food webs (Post 2002, Fry 2002, Bode et al. 2007).

Bulk tissue stable isotope analysis $\left(\mathrm{SIA}_{\mathrm{bulk}}\right)$ of nitrogen $\left(\delta^{15} \mathrm{~N}_{\text {bulk }}\right)$ and carbon $\left(\delta^{13} \mathrm{C}_{\text {bulk }}\right)$ has been used to determine energy sources, the flow of carbon to consumers in food webs, and the trophic positions of marine fishes (Peterson \& Fry 1987, Vander Zanden $\&$ Rasmussen 2001, Post 2002). Values of $\delta^{15} \mathrm{~N}$ indicate trophic positions of marine animals, as isotopic fractionation leads to an increase of the isotope values with increasing trophic levels. Values of $\delta^{13} \mathrm{C}_{\text {bulk }}$ 
show limited isotopic fractionation with increasing trophic level, thereby allowing for the assessment of baseline carbon sources of organisms when the isotopic nature of the sources vary, often due to the variation of $\delta^{13} \mathrm{C}_{\text {bulk }}$ among primary producers and their photosynthetic pathways (Peterson \& Fry 1987, Moncreiff \& Sullivan 2001, Post 2002).

Despite the usefulness of SIA $_{\text {bulk }}$ in evaluating diet and trophic relationships, there are limitations that can, when not appropriately addressed, cause large ecological misinterpretations in estimating the trophic level. $\delta^{15} \mathrm{~N}$ values increase (2-4\%) with each trophic level (Post 2002), but this ${ }^{15} \mathrm{~N}$-enrichment factor varies by consumer species, physiology, and diet (e.g. Martínez del Rio et al. 2009). Also, in the planktonic food web, it is necessary to characterize the $\delta^{15} \mathrm{~N}$ values of a known trophic position consumer as an ecosystem baseline (primary producers to primary consumers) to estimate the trophic level. However, the selection basis of baselines from plankton sizefractionated samples may present particular uncertainties regarding prey to consumer preferences (e.g. Popp et al. 2007). Different nitrogen sources for primary producers can have different $\delta^{15} \mathrm{~N}$ values that influence the nitrogen isotopic composition of consumers, yielding variable $\delta^{15} \mathrm{~N}$ values spatially and temporally within an ecosystem that are unrelated to trophic position (Post 2002). For example, primary producers in aquatic environments (e.g. cyanobacteria and algae) show spatial and temporal variability in their $\delta^{15} \mathrm{~N}$ values because of their assimilation of various nitrogen sources (atmospheric nitrogen fixation by diazotrophs or ammonium by recycled production) and the short lifespan of the organisms (McMahon et al. 2013).

Alternatively, compound-specific isotope analysis $\left(\mathrm{CSIA}_{\mathrm{AA}}\right)$ addresses the limitations of bulk SIA as it provides measurements of isotope ratios from individual amino acids (AAs) (Fantle et al. 1999, Fogel \& Tuross 2003). Diet composition and metabolic processes are reflected in the carbon and nitrogen isotopes found in AAs, $\delta^{15} \mathrm{~N}_{\mathrm{AA}}$ and $\delta^{13} \mathrm{C}_{\mathrm{AA}}$ (Boecklen et al. 2011). Variations in metabolic processing between the $\mathrm{C}-\mathrm{N}$ bonds result in discrimination between AAs, resulting in 2 categories when discussing $\delta^{15} \mathrm{~N}_{\mathrm{AA}}$ : trophic and source AAs. Trophic AAs like glutamic acid (Glu) and alanine (Ala) undergo considerable isotopic fractionation relative to diet, while source AAs such as glycine (Gly) and phenylalanine (Phe) exhibit little to no trophic fractionation during metabolic processes (Bradley et al. 2015, McMahon et al. 2015). For $\delta^{13} C_{A A}$ a similar scenario exists whereby values for non-essential AAs change considerably from diet to consumer while those for essential AAs do not (McMahon et al. 2010).

Comparisons of trophic and source $\delta^{15} \mathrm{~N}_{\mathrm{AA}}$ and essential and non-essential $\delta^{13} \mathrm{C}_{\mathrm{AA}}$ allow for estimations of primary production sources, which are reflected in variations among basal end-members, as well as greater resolution for trophic positions of organisms (McClelland \& Montoya 2002, Chikaraishi et al. 2009, Olson et al. 2010, McMahon et al. 2010, 2013). Moreover, CSIA $\mathrm{AA}_{\mathrm{A}}$ can complement whole-tissue or whole-animal isotopic signatures, and can distinguish metabolic and trophic-level relationships in a food web from changes in isotopic compositions at the base of the food web (Fantle et al. 1999, McClelland \& Montoya 2002). One of the major advantages of the CSIA $_{\mathrm{AA}}$ method is that the trophic position is estimated from 2 AAs from each individual, therefore characterization of the $\delta^{15} \mathrm{~N}$ values of the ecosystem baseline or other organisms used as reference is not required (McClelland \& Montoya 2002).

In marine environments, some fish species spawn and feed in separate areas and different seasons, and energy acquired through foraging throughout the year is stored for later reproduction. These species are called 'capital breeders' (Stephens et al. 2009). Other species, termed 'income breeders,' spawn using energy acquired locally throughout a protracted spawning season, allocating energy directly to reproduction (e.g. Anchoa mitchilli, Engraulidae) (McBride et al. 2015). Recent studies using SIA $_{\text {bulk }}$ in tuna larvae in the Mediterranean Sea revealed differences between preflexion and postflexion ontogenetic stages as a consequence of the maternal transmission of their isotopic signature (Uriarte et al. 2016, García et al. 2017). This finding allowed for the development of a maternal isotopic transmission model of $T$. thynnus using preflexion isotopic signatures, which reveals information on trophic dynamics of the breeders (Uriarte et al. 2016). Conversely, based on diet-switching feeding experiments, Tanaka et al. (2016) successfully demonstrated that Japanese anchovy Engraulis japonicus were income breeders because the $\delta^{15} \mathrm{~N}_{\text {bulk }}$ and $\delta^{13} \mathrm{C}_{\text {bulk }}$ ratios in eggs closely followed the isotope ratios of the food of adult fish. Under this paradigm, Mei et al. (2018) applied SIA on the smallest larvae of 6 mesopelagic species, which revealed the dominant spawning strategy (breeder type). Taking into account breeding type (income or capital breeder) of fishes may allow interpretation of differences or similarities between the SIA bulk $_{\text {ratios }}$ measured in field-captured fish larvae (Tanaka et al. 2016, Mei et al. 2018). 
The GOM pelagic ecosystem is a large, complex, and highly integrated system that provides habitat for large predatory fishes like tunas. Early life history studies on the survival of tuna species can provide insight to the recruitment success of adults (Houde 1987, Hare 2014). There have been some significant advances in the understanding of larval tuna ecology, though these studies mostly focused on T. thynnus (bluefin tuna, BFT) (Muhling et al. 2017). Uriarte et al. $(2018,2019)$ reported cannibalistic feeding behavior in the Mediterranean, Tilley et al. (2016) reported on feeding ecology in central GOM, and Domingues et al. (2016) reported on the variability of preferred environmental conditions in the GOM over time. Even with these advances, there still is limited knowledge of the trophic hierarchy and food web connections of larval tuna species in the offshore marine ecosystems of the Atlantic.

Here, we combined both SIA bulk and CSIA AA $_{\text {to }}$ evaluate the larval trophic ecology of 4 species of tuna in the GOM. We analyzed ontogenetic shifts in SIA $_{\text {bulk }}$ and CSIA ${ }_{\mathrm{AA}}$, and measured their isotopic niche width and overlap to reveal the trophic interactions, nutrient partitioning, and resource utilization among the 4 species. We then related SIA $_{\text {bulk }}$ and CSIA $_{A A}$ within each species to their spawning behavior to see if spawning strategy plays a role in the observed stable isotope patterns.

\section{MATERIALS AND METHODS}

\subsection{Field sampling of larvae and zooplankton}

A total of 76 stations were sampled aboard the R/V 'F. G. Walton Smith' between 28 April and 25 May 2014 in the northern GOM. Tuna larvae analyzed in this study were collected east of $90^{\circ} \mathrm{W}$ (Fig. 1) using similar methodologies described by Laiz-Carrión et al. (2015). At each station, a $1 \times 2 \mathrm{~m}$ (height $\times$ width frame) plankton net fitted with $505 \mu \mathrm{m}$ mesh was towed in an undulating manner through the upper $10 \mathrm{~m}$ of the water column for approximately $10 \mathrm{~min}$. Tuna larvae were sorted from the plankton samples immediately after retrieval of the net, and frozen in liquid nitrogen. A bongo net $(25 \mathrm{~cm}$ diameter) was fitted with 200 and $55 \mu \mathrm{m}$ mesh nets to target mesoand microzooplankton, respectively. The bongo net was towed for $5 \mathrm{~min}$ in a similar undulating manner from 0 to $10 \mathrm{~m}$. A mechanical flowmeter (2030, Gen-

eral Oceanics) was placed in the center of all plankton net openings to calculate the volume of water filtered $\left(\mathrm{m}^{3}\right)$ by each net. Plankton from the $200 \mu \mathrm{m}$ net (hereafter mesozooplankton) were divided into 2 aliquots using a Folsom plankton splitter, with half preserved in $95 \%$ ethanol, and the other half frozen at $-20^{\circ} \mathrm{C}$. The sample from the $55 \mu \mathrm{m}$ mesh net (hereafter microzooplankton) was first poured through a $200 \mu \mathrm{m}$ mesh sieve to remove larger zooplankton, collected on a $55 \mu \mathrm{m}$ mesh, then frozen at $-20^{\circ} \mathrm{C}$. Each mesozooplankton and microzooplankton sample was freeze-dried for $48 \mathrm{~h}$ at $-20^{\circ} \mathrm{C}$, and weighed to the nearest $1 \mu \mathrm{g}$. Dry weight (DW) biomass values were standardized to $\mathrm{mg} \mathrm{m}^{-3}$. Hydrographic data including salinity, temperature $\left({ }^{\circ} \mathrm{C}\right)$ and dissolved oxygen $\left(\mathrm{mg} \mathrm{l}^{-1}\right)$ were collected at each sampling station using a Seabird SBE 9/11 Plus CTD profiler equipped with a dissolved oxygen sensor (SBE 43) 
deployed to a depth of $200 \mathrm{~m}$, or within $10 \mathrm{~m}$ of the seabed at shallow stations.

\subsection{SIA $A_{\text {bulk }}$}

Four larval tuna species were selected for SIA $_{\text {bulk }}$ (see Fig. 2). Larvae were transferred from liquid nitrogen to a $-80^{\circ} \mathrm{C}$ freezer. The subsequent handling and treatment of larvae are described in García et al. (2006) and Laiz-Carrión et al. (2013, 2015). Body length was measured as standard length (SL) using the image analysis software ImageJ (National Institutes of Health, https://imagej.nih.gov/ij/) after the larvae were thawed at room temperature. Only larvae that measured between 4 and $8 \mathrm{~mm}$ SL were selected, to avoid yolk sac stages. Subsequently, larvae were dehydrated in a freeze dryer for $24 \mathrm{~h}$. Larval DW (mg) was measured and stomach contents were removed. Dried larvae were packed in tin vials $(0.03 \mathrm{ml})$ for $\mathrm{SIA}_{\text {bulk }}$. Stable isotope ratios of nitrogen $\left(\delta^{15} \mathrm{~N}_{\text {bulk }}\right.$ and $\% \mathrm{~N})$ and carbon $\left(\delta^{13} \mathrm{C}_{\text {bulk }}\right.$ and $\left.\% \mathrm{C}\right)$ were measured using an isotope-ratio mass spectrometer (ThermoFinnigan Deltaplus; www.thermoscientific.com) coupled to an elemental analyzer (FlashEA1112 ThermoFinnigan) at the Instrumental Unit of Analysis of the University of A Coruña. Ratios of ${ }^{15} \mathrm{~N}:{ }^{14} \mathrm{~N}$ and ${ }^{13} \mathrm{C}:{ }^{12} \mathrm{C}$ were expressed in conventional delta notation $(\delta)$, relative to the international standards atmospheric air $\left(\mathrm{N}_{2}\right)$ and Pee-Dee Belemnite (PDB), respectively, using acetanilide as standard (Fry 2002). The accuracy of the measurements for $\delta^{15} \mathrm{~N}_{\text {bulk }}$ and $\delta^{13} \mathrm{C}_{\text {bulk }}$ were 0.18 and $0.20 \%$, respectively.

A mathematical correction of $\delta^{13} \mathrm{C}$ values for lipid content was performed for the corresponding plankton size fractions. An average of the 4 equations proposed by Logan et al. (2008) using the parameters of Thunnus thynnus muscle was applied for lipid correction in scombrid larvae, and with marine invertebrate parameters for micro- and mesozooplankton size fractions. The lipid correction models were applied to estimate a mean $( \pm \mathrm{SD})$ correction value of $2.09 \pm 0.53,0.99 \pm 0.13$, and $0.61 \pm 0.19 \%$ for larvae, micro-, and mesozooplankton, respectively. This procedure has been previously described by LaizCarrión et al. $(2013,2015)$. These values were used for the $\delta^{13} \mathrm{C}$ lipid correction in both zooplankton size fractions. For lipid correction of tuna larvae, the parameters of $T$. thynnus muscle were used from Laiz-Carrión et al. $(2013,2015)$. Hereafter, $\delta^{13} \mathrm{C}_{\text {bulk }}$ will refer to lipid-corrected values.

Trophic position (TP) for each tuna species (T. thynnus, T. atlanticus, Katsuwonus pelamis, and Auxis rochei) was estimated using the following equation (Laiz-Carrión et al. 2015):

$$
\mathrm{TP}_{\text {bulk }}=\mathrm{TP}_{\text {basal }}+\left(\delta^{15} \mathrm{~N}_{\text {Larva }}-\delta^{15} \mathrm{~N}_{\text {Micro }}\right) / \delta^{15} \mathrm{~N}
$$

where $\delta^{15} \mathrm{~N}_{\text {Larva }}$ is the isotopic signature for each individual tuna larva and $\delta^{15} \mathrm{~N}_{\text {micro }}$ is the isotopic value of microzooplankton of the station. We applied a basal trophic position ( $\mathrm{TP}_{\text {basal }}$ ) of 2, assuming microzooplankton as primary consumers (Bode et al. 2007, Coll et al. 2006). A mean nitrogen isotopic discrimination factor $\left(\delta^{15} \mathrm{~N}\right)$ of $1.64 \%$ was used, as proposed by Varela et al. (2011) for T. thynnus juveniles. Only postflexion tuna larvae were used for the comparative $\mathrm{TP}$, isotopic niche width, and overlap analyses to avoid influence of maternally transmitted isotopes in preflexion and flexion tuna larvae (Uriarte et al. 2016, García et al. 2017).

\subsection{Isotopic niche width and overlap}

Isotopic niche analyses followed Suca \& Llopiz (2017) and Suca et al. (2018). Briefly, standard ellipse areas using the variance and covariance of $\delta^{13} \mathrm{C}_{\text {bulk }}$ and $\delta^{15} \mathrm{~N}_{\text {bulk }}$ values were calculated with a sample size correction using the following equation:

$$
\mathrm{SEA}_{\mathrm{C}}=\operatorname{SEA} \times(\mathrm{n}-1) /(\mathrm{n}-2)
$$

where $\mathrm{SEA}_{\mathrm{C}}$ is the standard ellipse area corrected for sample size, SEA is the standard ellipse area, and $\mathrm{n}$ is the number of samples for a particular species (Batschelet 1981, Ricklefs \& Nealen 1998, Jackson et al. 2011, 2012). The overlap of these sample size corrected standard ellipse areas provides an estimate for isotopic niche overlap between species (Jackson et al. 2012). Bayesian standard ellipse areas $\left(\mathrm{SEA}_{B}\right)$ and associated credible intervals were calculated as described in Jackson et al. (2011). The mode and credible intervals were determined from 4000 estimated of $\mathrm{SEA}_{B}$ using posterior distributions calculated from vague normal priors, combined with likelihood values formed from the isotope data. Isotopic niche widths and overlap analyses were conducted using the $\mathrm{R}$ package SIBER (stable isotope Bayesian ellipses in R) v.3.3.0 (Jackson et al. 2011, R Development Core Team 2012).

\section{4. $\operatorname{CSIA}_{\mathrm{AA}}$}

A total of 297 tuna larvae (3.6 to $9.6 \mathrm{~mm} \mathrm{SL}$ ) from the GOM (independent from larvae chosen for 
Table 1. Larval tuna species from the Gulf of Mexico analyzed for compound-specific isotope analysis (CSIA) of amino acids $\left(\delta^{15} \mathrm{~N}_{\mathrm{AA}}\right.$ and $\left.\delta^{13} \mathrm{C}_{\mathrm{AA}}\right)$ with corresponding developmental stages and standard length (SL) ranges. No. pooled for $\mathrm{CSIA}_{\mathrm{AA}}$ : number of samples of pooled larvae analyzed for each group

\begin{tabular}{|lcccc|}
\hline Species & $\begin{array}{c}\text { Developmental } \\
\text { stage }\end{array}$ & $\begin{array}{c}\text { No. of } \\
\text { larvae }\end{array}$ & $\begin{array}{c}\text { SL } \\
(\mathrm{mm})\end{array}$ & $\begin{array}{c}\text { No. pooled } \\
\text { for CSIA }_{\mathrm{AA}}\end{array}$ \\
\hline Thunnus thynnus & $\begin{array}{c}\text { Preflexion } \\
\text { T. atlanticus }\end{array}$ & 71 & $4.6-5.8$ & 2 \\
& Postflexion & 30 & $6.3-8.6$ & 3 \\
Auxis rochei & Preflexion & 58 & $3.6-6.3$ & 2 \\
& Postflexion & 30 & $6.3-9$ & 3 \\
Katsuwonus pelamis & Preflexion & - & - & - \\
& Postflexion & 34 & $4.9-8.6$ & 3 \\
& Preflexion & 61 & $3.8-6.9$ & 2 \\
& Postflexion & 13 & $7-9.6$ & 2 \\
\hline
\end{tabular}

$\mathrm{SIA}_{\text {bulk }}$ ) were selected for $\mathrm{CSIA}_{\mathrm{AA}}$ : 101 T. thynnus, $88 \mathrm{~T}$. atlanticus, $34 \mathrm{~A}$. rochei, and $74 \mathrm{~K}$. pelamis (Table 1). Larvae were pooled to attain the smallest weight that CSIA $_{\mathrm{AA}}$ analysis requires (3 to $5 \mathrm{mg}$ DW), according to their ontogenetic stage and SL (Table 1). CSIA AA $_{\text {a }}$ was performed using a Thermo GC-C-IRMS system (Stable Isotope Facility at University of California Davis), composed of a Trace GC Ultra gas chromatograph (Thermo Electron) coupled to a Delta V Advantage isotope ratio mass spectrometer through either a GC/C-III (C analysis) or GC IsoLink ( $\mathrm{N}$ analysis) interface (Thermo Electron), with a combustion at $1000^{\circ} \mathrm{C}$ with $\mathrm{Ni} / \mathrm{NiO} / \mathrm{CuO}$ catalyst. Compound identification support for the CSIA $_{\mathrm{AA}}$ laboratory was provided by a Varian CP3800 gas chromatograph coupled to a Saturn 2200 ion trap MS/MS (Varian; see Walsh et al. 2014 for sample treatment details).

TP based on CSIA $_{\mathrm{AA}}$ for each tuna species ( $T$. thynnus, T. atlanticus, K. pelamis, and A. rochei; $\left.\mathrm{TP}_{\text {CSIA }}\right)$ was estimated only in postflexion larvae following the model proposed by Bradley et al. (2015) for teleost fish modified from Chikaraishi et al. (2009):

$$
\mathrm{TP}_{\mathrm{CSIA}}=1+\left(\delta^{15} \mathrm{~N}_{\mathrm{Glu}}-\delta^{15} \mathrm{~N}_{\mathrm{Phe}}-3.4\right) / 5.7
$$

\subsection{Statistical analysis}

One-way ANOVA (homogenous variance) was used to assess differences in environmental variables and $\delta^{13} \mathrm{C}$ and $\delta^{15} \mathrm{~N}$ values among the tuna species. Differences in morphology (DW and SL) among species were tested using ANCOVA, with DW (logtransformed) or SL as a covariate. Larval developmental stage (pre- and postflexion) effect on isotopic signature was tested by 1-way ANOVA. CSI-
$\mathrm{A}_{\mathrm{AA}}$ data were assessed by a 2-way ANOVA in which 4 species (T. thynnus, T. atlanticus, A. rochei, and $K$. pelamis) and AAs (nitrogen and carbon isotopic compositions) were the main factors, and treated as nominal independent variables. Analyses to test the normality (Kolmogorov-Smirnov) and to verify the homogeneity of variances were executed prior to ANOVA analyses. Logarithmic transformations of the data were made when necessary to fulfill the conditions of the ANOVA, but data are shown in their decimal values for clarity. Post hoc comparisons were made using a Tukey test. These results were generated using the Statistica v.7.1 (Statsoft) software package at a significance level of $\alpha<0.05$.

\section{RESULTS}

\subsection{Environmental data}

Among species, there were no significant differences in temperature, salinity, oxygen, fluorescence, maximum fluorescence at the deep chlorophyll maximum, at either the surface or $100 \mathrm{~m}$ among stations where larvae were collected. Further, no significant differences (ANOVA, $F_{3,27}=0.33, \mathrm{p}>0.05$ ) occurred for the biomass of the micro- and mesozooplankton fractions, carbon and nitrogen composition (\%), or their isotopic signatures $\left(\delta^{13} \mathrm{C}\right.$ and $\left.\delta^{15} \mathrm{~N}\right)$ (Table 2$)$.

\subsection{Larval tuna cohorts: morphometric features comparison}

The larval tuna samples selected for this study did not show significant differences in their size range (SL) (Fig. 2). Their SL varied from 3.8 to $8.1 \mathrm{~mm}$ (mean $\pm \mathrm{SD}: 5.89 \pm 0.95 \mathrm{~mm}$ ) in all samples of tuna larvae $(\mathrm{n}=192)$ (Table 3$)$.

Dry weight at standard length was significantly higher for Thunnus thynnus and Auxis rochei than for Katsuwonus pelamis and T. atlanticus (ANCOVA, $F_{3,187}=5.60, \mathrm{p}<0.05$; Fig. 3). T. thynnus showed a significantly lower weight at length than the other tuna species (ANCOVA, $F_{3,187}=6.54, \mathrm{p}<0.05$ ). Significant differences were observed in DW among species (ANOVA, $\left.F_{3,188}=2.64, \mathrm{p}<0.05\right)$, with $K$. pelamis having a significantly greater DW at length than $T$. thynnus (Tukey's HSD, p < 0.05). 
Table 2. Mean $( \pm \mathrm{SE})$ of the environmental variables for the study area of each tuna species; microzooplankton and mesozooplankton size fractions are also shown. SST: sea surface temperature; SSS: sea surface salinity; SSO: sea surface oxygen; SSF: sea surface fluorescence; $T_{100}$ : temperature at $100 \mathrm{~m}$ depth; $\mathrm{S}_{100}$ : salinity at $100 \mathrm{~m}$ depth; $\mathrm{O}_{100}$ : oxygen at $100 \mathrm{~m}$ depth; $\mathrm{F}_{100}$ : raw fluorescence at $100 \mathrm{~m} \mathrm{depth}$; fluro. max.: maximum raw fluorescence; depth fluro. max.: depth at maximum raw fluorescence. None of the values are significantly different (ANOVA, $p>0.05$ )

\begin{tabular}{|c|c|c|c|c|}
\hline & Thunnus thynnus & T. atlanticus & Katsuwonus pelamis & Auxis rochei \\
\hline \multicolumn{5}{|l|}{ Environmental variables } \\
\hline $\operatorname{SST}\left({ }^{\circ} \mathrm{C}\right)$ & $24.59 \pm 0.14$ & $24.76 \pm 0.16$ & $24.61 \pm 0.13$ & $24.59 \pm 0.15$ \\
\hline SSS (ppm) & $35.77 \pm 0.37$ & $35.45 \pm 0.43$ & $34.95 \pm 0.35$ & $35.62 \pm 0.40$ \\
\hline $\mathrm{SSO}\left(\mathrm{mg} \mathrm{l}^{-1}\right)$ & $5.66 \pm 0.14$ & $5.73 \pm 0.17$ & $5.85 \pm 0.14$ & $5.81 \pm 0.15$ \\
\hline $\mathrm{SSF}\left(\mathrm{mg} \mathrm{m}^{-3}\right)$ & $0.44 \pm 0.02$ & $0.43 \pm 0.02$ & $0.45 \pm 0.02$ & $0.46 \pm 0.02$ \\
\hline$T_{100}\left({ }^{\circ} \mathrm{C}\right)$ & $17.75 \pm 0.26$ & $18.43 \pm 0.30$ & $18.25 \pm .24$ & $18.00 \pm 0.27$ \\
\hline $\mathrm{S}_{100}(\mathrm{ppm})$ & $36.30 \pm 0.03$ & $36.40 \pm 0.03$ & $36.36 \pm 0.03$ & $36.35 \pm 0.03$ \\
\hline $\mathrm{O}_{100}\left(\mathrm{mg} \mathrm{l}^{-1}\right)$ & $4.51 \pm 0.14$ & $4.54 \pm 0.16$ & $4.48 \pm 0.13$ & $4.36 \pm 0.15$ \\
\hline $\mathrm{F}_{100}\left(\mathrm{mg} \mathrm{m}^{-3}\right)$ & $0.44 \pm 0.05$ & $0.50 \pm 0.05$ & $0.48 \pm 0.04$ & $0.46 \pm 0.05$ \\
\hline Fluro. max. $\left(\mathrm{mg} \mathrm{m}^{-3}\right)$ & $1.27 \pm 0.08$ & $1.20 \pm 0.09$ & $1.54 \pm 0.07$ & $1.51 \pm 0.08$ \\
\hline Depth fluro. max. (m) & $-63.88 \pm 3.30$ & $-64.83 \pm 3.81$ & $-65.22 \pm 3.11$ & $-64.57 \pm 3.53$ \\
\hline \multicolumn{5}{|l|}{ Trophic variables } \\
\hline \multicolumn{5}{|l|}{ Microzooplankton } \\
\hline Biomass $\left(\mathrm{mg} \mathrm{m}^{-3}\right)$ & $1.78 \pm 0.17$ & $1.53 \pm 0.20$ & $1.33 \pm 0.16$ & $1.67 \pm 0.18$ \\
\hline$\% \mathrm{~N}$ & $7.30 \pm 0.35$ & $6.14 \pm 0.41$ & $6.72 \pm 0.33$ & $7.03 \pm 0.38$ \\
\hline$\delta^{15} \mathrm{~N}_{\text {bulk }}(\%$ $)$ & $2.77 \pm 0.06$ & $2.55 \pm 0.07$ & $2.72 \pm 0.06$ & $2.66 \pm 0.07$ \\
\hline$\% \mathrm{C}$ & $34.80 \pm 1.48$ & $30.07 \pm 1.71$ & $32.45 \pm 1.39$ & $33.89 \pm 1.58$ \\
\hline$\delta^{13} \mathrm{C}_{\text {bulk }}(\%$ o) & $-19.48 \pm 0.13$ & $-19.55 \pm 0.15$ & $-19.61 \pm 0.12$ & $-19.59 \pm 0.14$ \\
\hline $\mathrm{C} / \mathrm{N}$ ratio & $4.80 \pm 0.08$ & $4.86 \pm 0.09$ & $4.84 \pm 0.08$ & $4.84 \pm 0.09$ \\
\hline \multicolumn{5}{|l|}{ Mesozooplankton } \\
\hline Biomass $\left(\mathrm{mg} \mathrm{m}^{-3}\right)$ & $21.74 \pm 2.78$ & $20.11 \pm 3.21$ & $15.96 \pm 2.62$ & $22.72 \pm 2.98$ \\
\hline$\% \mathrm{~N}$ & $7.59 \pm 0.33$ & $7.28 \pm 0.38$ & $8.12 \pm 0.31$ & $7.94 \pm 0.36$ \\
\hline$\delta^{15} \mathrm{~N}_{\text {bulk }}(\%$ o) & $3.91 \pm 0.15$ & $3.75 \pm 0.17$ & $4.20 \pm 0.14$ & $4.00 \pm 0.16$ \\
\hline$\% \mathrm{C}$ & $28.61 \pm 1.04$ & $27.97 \pm 1.20$ & $30.87 \pm 0.98$ & $29.82 \pm 1.11$ \\
\hline$\delta^{13} \mathrm{C}_{\text {bulk }}(\%$ \%) & $-20.41 \pm 0.11$ & $-20.36 \pm 0.12$ & $-20.52 \pm 0.10$ & $-20.63 \pm 0.11$ \\
\hline $\mathrm{C} / \mathrm{N}$ ratio & $3.77 \pm 0.05$ & $3.85 \pm 0.05$ & $3.82 \pm 0.04$ & $3.77 \pm 0.05$ \\
\hline
\end{tabular}

\subsection{SIA $\mathrm{Aulk}_{\text {bul }}$}

The $\delta^{15} \mathrm{~N}_{\text {bulk }}$ values were significantly higher in $T$. thynnus larvae than in the other 3 species (ANOVA, $F_{3,188}=64.74, \mathrm{p}<0.01$; Table 3). No differences were observed among the 3 other tuna species. $\delta^{13} \mathrm{C}_{\text {bulk }}$ values were significantly higher for $T$. thynnus and $T$. atlanticus than $A$. rochei and $K$. pelamis (ANOVA, $F_{3,188}=15.84, \mathrm{p}<0.01 ;$ Table 3$)$.

The average $\delta^{15} \mathrm{~N}$ by size class for the 4 species (Fig. 4) showed a decreasing trend in the early stages of development (preflexion) in the 4 species, until flexion occurs at approximately 5.5 to $6 \mathrm{~mm}$. T. thynnus showed a significantly higher $\delta^{15} \mathrm{~N}_{\text {bulk }}$ signature than the other tuna larvae in every size class (ANOVA, $\left.F_{11,179}=2.56, \mathrm{p}<0.05\right)$, with highest values observed in the smallest $T$. thynnus larvae (4 $\mathrm{mm}$ size class; ANOVA, $F_{3,179}=19.571$, p < 0.05).

Larvae of the 4 species showed a greater $\delta^{15} \mathrm{~N}$ average than the mesozooplankton and the microzooplankton fractions (baseline), which showed the lowest signatures (Fig. 5). Highest $\delta^{15} \mathrm{~N}$ values were observed in T. thynnus larvae. Higher mean values of $\delta^{13} \mathrm{C}$ were found in both $T$. thynnus and T. atlanticus, whereas the lowest $\delta^{13} \mathrm{C}$ values belonged to the mesozooplanton biomass fraction (Fig. 5).

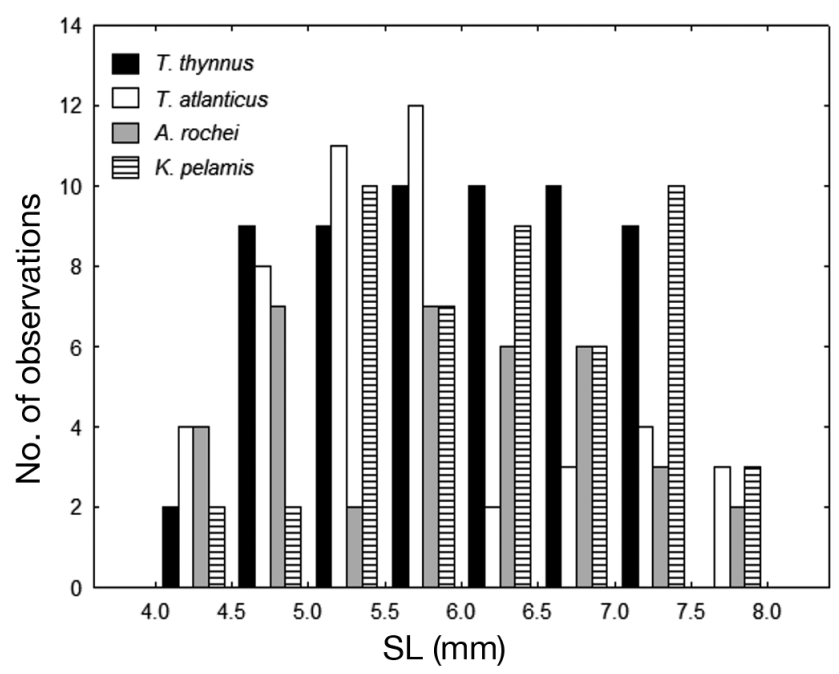

Fig. 2. Standard length (SL) distributions for the 4 larval tuna species: Thunnus thynnus, T. atlanticus, Auxis rochei, and Katsuwonus pelamis from the Gulf of Mexico 
Table 3. Standard length (SL) ranges and mean $( \pm \mathrm{SD})$ of 4 larval tuna species analyzed for bulk stable isotope analysis $\left(\mathrm{SIA}_{\text {bulk }}\right)$ from the Gulf of Mexico. Different letters next to the values indicate significant differences $(\mathrm{p}<0.05)$ among species

\begin{tabular}{|c|c|c|c|c|c|c|c|c|c|c|}
\hline Species & $\begin{array}{c}\text { No. } \\
\text { of } \\
\text { larvae }\end{array}$ & $\begin{array}{c}\text { Max. } \\
\text { SL } \\
(\mathrm{mm})\end{array}$ & $\begin{array}{l}\text { Min. } \\
\text { SL } \\
(\mathrm{mm})\end{array}$ & $\begin{array}{c}\mathrm{SL} \\
(\mathrm{mm})\end{array}$ & $\begin{array}{c}\text { Max. } \\
\delta^{15} \mathrm{~N}_{\text {bulk }} \\
(\% \text { oo })\end{array}$ & $\begin{array}{c}\text { Min. } \\
\delta^{15} \mathrm{~N}_{\text {bulk }} \\
(\% \text { o })\end{array}$ & $\begin{array}{c}\delta^{15} \mathrm{~N}_{\text {bulk }} \\
(\%)\end{array}$ & $\begin{array}{c}\text { Max. } \\
\delta^{13} \mathrm{C}_{\text {bulk }} \\
(\% o)\end{array}$ & $\begin{array}{c}\text { Min. } \\
\delta^{13} \mathrm{C}_{\text {bulk }} \\
(\% \text { o })\end{array}$ & $\begin{array}{c}\delta^{13} \mathrm{C}_{\text {bulk }} \\
(\% \text { o })\end{array}$ \\
\hline Thunnus thynnus & 59 & 7.42 & 4.22 & $5.94 \pm 0.89$ & 7.25 & 3.78 & $5.62 \pm 0.81 \mathrm{a}$ & -18.35 & -19.94 & $-19.29 \pm 0.41 \mathrm{a}$ \\
\hline T. atlanticus & 47 & 7.85 & 4.36 & $5.70 \pm 0.93$ & 5.41 & 3.39 & $4.35 \pm 0.43 b$ & -18.67 & -19.60 & $-19.24 \pm 0.23 a$ \\
\hline Auxis rochei & 37 & 7.81 & 4.18 & $5.86 \pm 1.03$ & 5.70 & 3.63 & $4.16 \pm 0.50 b$ & -18.42 & -20.23 & $-19.62 \pm 0.42 b$ \\
\hline Katsuwonus pelamis & 49 & 7.93 & 4.17 & $6.20 \pm 0.97$ & 6.58 & 3.19 & $4.25 \pm 0.56 b$ & -18.98 & -20.14 & $-19.61 \pm 0.32 b$ \\
\hline
\end{tabular}

\subsection{Isotopic niche widths and overlap}

K. pelamis showed the largest trophic niche through $\mathrm{SEA}_{\mathrm{C}}\left(\%^{2}\right)$, and $\mathrm{SEA}_{\mathrm{B}}$ (Fig. 6). The larval isotopic niche of the genus Thunnus overlapped from $18.6 \%$ (T. thynnus overlap with T. atlanticus) to $17.4 \%$ (T. atlanticus overlap with $T$. thynnus), whereas $A$. rochei and $K$. pelamis overlapped $56.8 \%$ (A. rochei overlap with $K$. pelamis) to $31.2 \%$ (K. pelamis overlap with A. rochei; Table 4). Moreover, T. thynnus, T. atlanticus, and $A$. rochei showed a trophic niche overlap (15.8 to $56.8 \%$ ) with $K$. pelamis. No isotopic niche overlap was observed between $A$. rochei and T. thynnus or T. atlanticus.

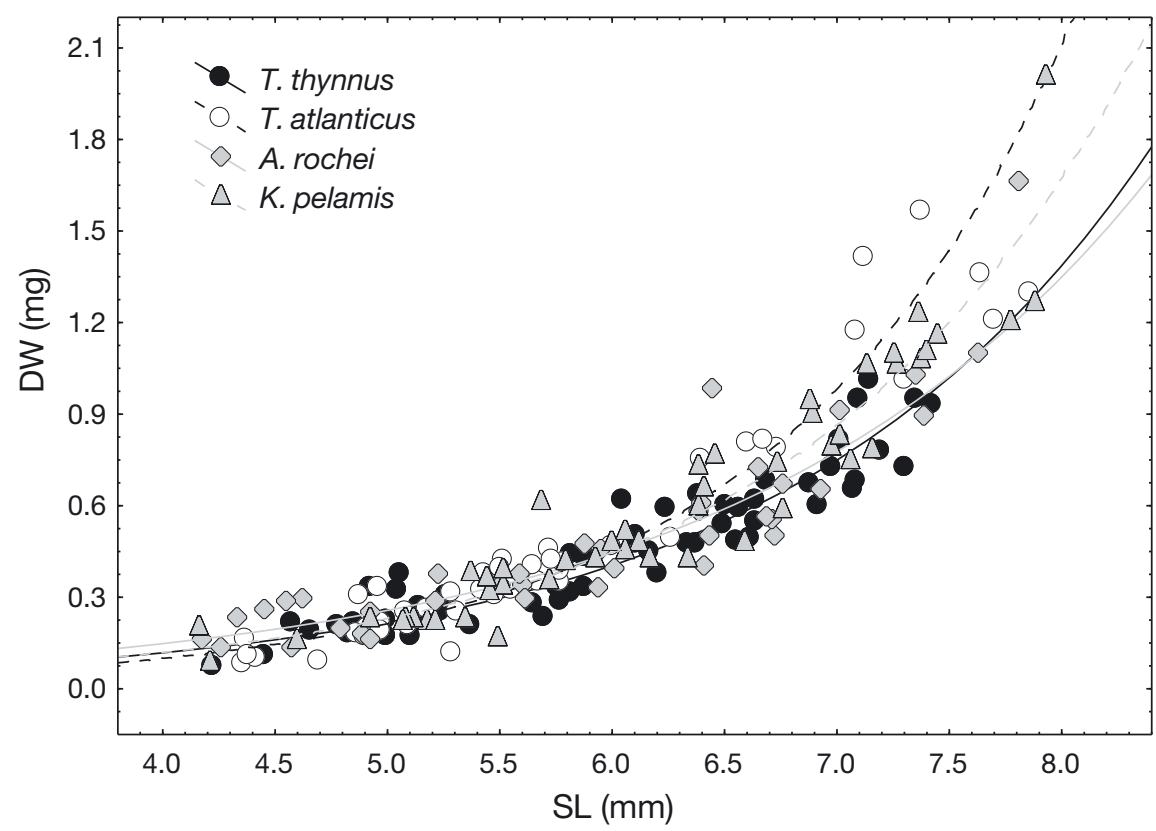

Fig. 3. Larval dry weight (DW) and body length (SL) relationships for Thunnus thynnus, T. atlanticus, Auxis rochei and Katsuwonus pelamis from the Gulf of Mexico. The curves were fitted by T. thynnus: $y=0.01 \exp 0.617 x(\mathrm{r}=0.926, \mathrm{p}<$ $0.01) ; T$. atlanticus: $y=0.005 \exp 0.763 x(\mathrm{r}=0.946, \mathrm{p}<0.01) ;$ A. rochei: $y=$ $0.016 \exp 0.553 x(\mathrm{r}=0.864, \mathrm{p}<0.01) ; K$. pelamis: $y=0.009 \exp 0.660 x(\mathrm{r}=0.910$, $\mathrm{p}<0.01)$

\subsection{CSIA $_{\mathrm{AA}}$}

AAs considered 'source AAs' (methionine [Met], lysine [Lys], glycine [Gly], and phenylalanine [Phe]) had relatively low $\delta^{15} \mathrm{~N}_{\mathrm{AA}}$ values, ranging from -3.33 to $3.54 \%$ o (Fig. 7A). 'Trophic AAs' (glutamic acid [Glu], valine [Val], alanine [Ala], isoleucine [Ile], leucine [Leu], aspartic acid [Asp], and proline [Pro]) had relatively high $\delta^{15} \mathrm{~N}_{\mathrm{AA}}$ values, varying from 7.51 to $14.31 \%$ in the 4 species analyzed (Fig. 7A). We found significant differences between source and trophic $\delta^{15} \mathrm{~N}_{\mathrm{AA}}$ values (2-way ANOVA, $F_{1,124}=674.69$, $\mathrm{p}<0.001$ ) among the 4 species (Fig. 7A). Significant differences were observed in source AAs, with higher values for Phe in T. thynnus and lower Lys values for $A$. rochei. The only significant difference observed for trophic AA was in Pro, with higher values for $T$. thynnus compared to the other 3 species, showing the same pattern observed with $\delta^{15} \mathrm{~N}_{\text {bulk }}$ (see Fig. 7A).

$\delta^{13} \mathrm{C}$ values of non-essential amino acids (NEAAs) were usually the most ${ }^{13} \mathrm{C}$-enriched AAs in the 4 species, ranging from -21.08 to $-12.15 \%$ whereas essential amino acids (EAAs) were usually the most ${ }^{13} \mathrm{C}$-depleted AAs in all 4 tuna species, with values ranging from -29.57 to $-16.02 \%$. We found significant differences between NEAAs and EAAs (Fig. 7B) (2-way ANOVA, $F_{1,124}=124.62, \mathrm{p}<$ 0.001 ) among the 4 species. Significant differences were observed in Gly with lower values for $K$. pelamis than the other 3 species (Fig. 7B). No differences were observed between pre- and postflexion stages in NEAAs and EAAs for the 4 species analyzed. 


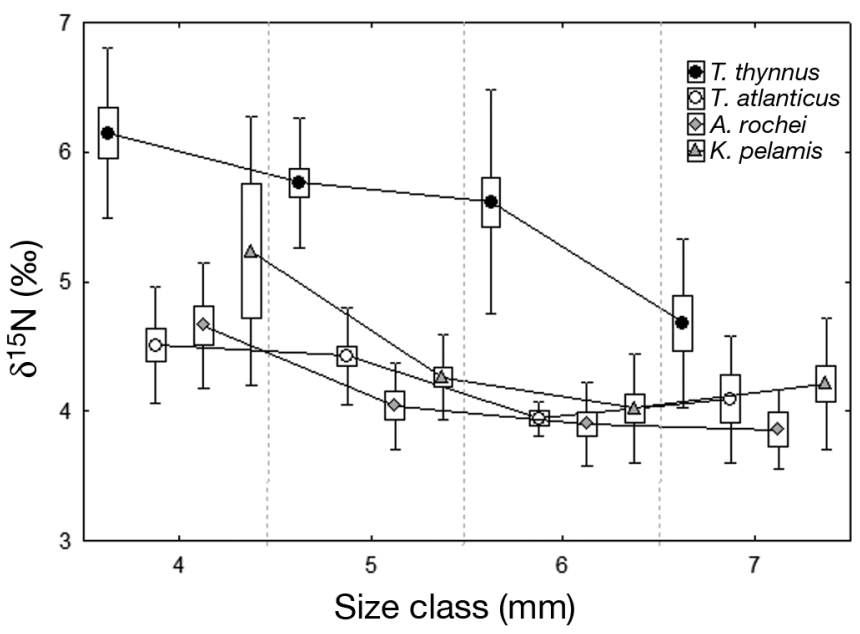

Fig. 4. Mean $\delta^{15} \mathrm{~N}_{\text {bulk }}$ by size class for larval Thunnus thynnus, T. atlanticus, Auxis rochei, and Katsuwonus pelamis from the Gulf of Mexico. Boxes: SE; whiskers: SD

\subsection{Preflexion vs. postflexion stage isotopic signatures}

Postflexion larvae were treated separately for both SIA $_{\text {bulk }}$ and CSIA $A$ analyses in order to avoid the maternal effect in preflexion larvae. The only species that showed significant differences between pre- and postflexion larvae SIA bulk was T. thynnus (ANOVA, $\left.F_{3.57}=97.66, \mathrm{p}<0.01\right)$, with higher $\delta^{15} \mathrm{~N}_{\text {bulk }}$ values in preflexion individuals (Fig. 8A). The same trend was observed for CSIA $_{\mathrm{AA}}$, with significantly higher values

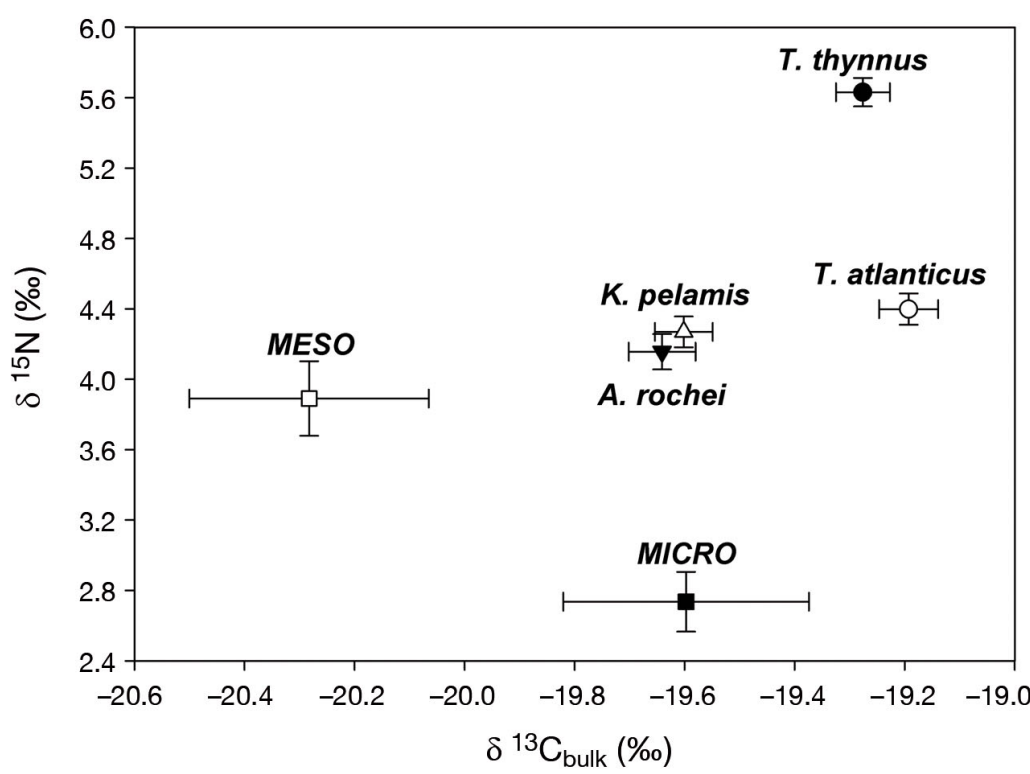

Fig. 5. Mean $( \pm \mathrm{SE}) \delta^{13} \mathrm{C}_{\text {bulk }}$ versus $\delta^{15} \mathrm{~N}_{\text {bulk }}$ in tuna larvae for Thunnus thynnus, T. atlanticus, Auxis rochei, and Katsuwonus pelamis from the Gulf of Mexico. Microzooplankton (50-200 $\mu \mathrm{m})$ as primary consumers were used as a baseline. $\delta^{13} \mathrm{C}^{\prime}$ denotes lipid-corrected values in preflexion stages than the postflexion T. thynnus larvae in trophic AAs (ANOVA, $F_{1,21}=28.69$, p < 0.001 ) and source AAs (ANOVA $F_{1.12}=17.72, \mathrm{p}<$ $0.001)$, especially in Met $(p<0.001)$ and Phe $(p<0.05$; Fig. 8B). No differences in $\delta^{15} \mathrm{~N}_{\mathrm{AA}}$ of either trophic or source AAs were observed between pre- and postflexion stages in the other 3 tuna species. No differences in $\delta^{13} \mathrm{C}_{\mathrm{AA}}$ were observed between pre- and postflexion stages in NEAAs (ANOVA, $F_{2.68}=0.26$, $\mathrm{p}>0.05$ ) and EAAs (ANOVA, $F_{2.83}=0.02, \mathrm{p}>0.05$ ) for any of the species analyzed.

\subsection{TP comparison}

Using SIA $\mathrm{Aulk}_{\text {buth }}$ wicrozooplankton as a primary consumer baseline, T. thynnus had a significantly higher TP (mean \pm SD: $2.76 \pm 0.23$, ranging from 3.73 to 2.22$)$ than $K$. pelamis $(2.41 \pm 0.26,3.01$ to 2.00$), T$. atlanticus $(2.30 \pm 0.23,2.66$ to 1.90$)$, and $A$. rochei $(2.29 \pm 0.20,2.91$ to 2.10$)$ (Table 5). However, when TP was estimated by CSIA $_{A A}$, no significant differences among species were observed (Table 5).

\section{DISCUSSION}

This study indicates that the nutrient utilization of Thunnus thynnus, T. atlanticus, Katsuwonus pelamis, and Auxis rochei larvae varies among species throughout ontogeny. SIA bulk $_{\text {revealed differ- }}$ ences in the isotopic niche width among the 4 species, indicating that postflexion K. pelamis and $A$. rochei utilize a broader range of nutrient sources than $T$. thynnus or $T$. atlanticus, likely stemming from the greater vertical range of $K$. pelamis and $A$. rochei and their dependence on appendicularians as prey (Llopiz et al. 2010). Further, while SIA bulk $_{\text {sug- }}$ gests that $T$. thynnus occupies a higher trophic position than the other 3 species, CSI$\mathrm{A}_{\mathrm{AA}}$ indicates that this elevated trophic position could be affected by higher $\delta^{15} \mathrm{~N}$ in source AAs, and thus T. thynnus does not truly occupy a higher trophic position. The maternal effect of higher source AA (Phe) and bulk $\delta^{15} \mathrm{~N}$ values in preflexion than postflexion $T$. thynnus larvae, and the overall higher values when compared to the other 3 species, is likely a result of the 'capital breeder' strategy of $T$. thynnus, whereby energy used for gamete production was obtained from foraging prior to spawning, and from a different 

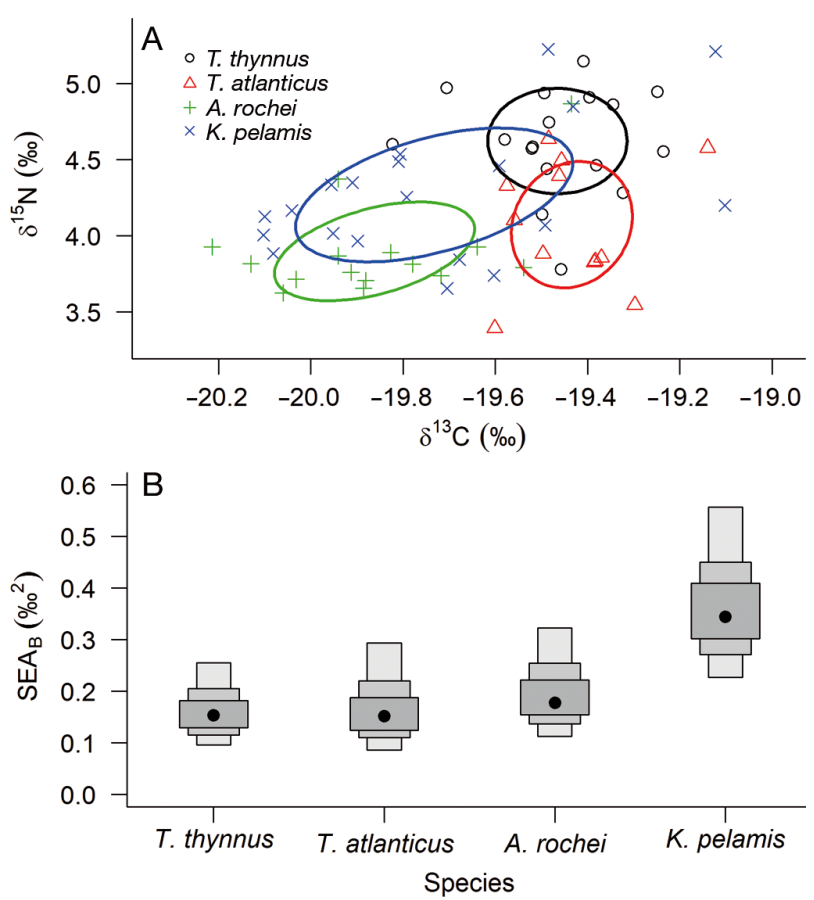

Fig. 6. (A) Scatter biplots of $\delta^{13} \mathrm{C}_{\text {bulk }}$ and $\delta^{15} \mathrm{~N}_{\text {bulk }}$ values in postflexion larvae for Thunnus thynnus, T. atlanticus, Auxis rochei, and Katsuwonus pelamis from the Gulf of Mexico. Ellipses: isotopic niche width for each species. (B) Trophic niche width as the sample size-corrected Bayesian standard ellipse area $\left(\mathrm{SEA}_{B}\right)$. Density plot shows the confidence intervals of the standard ellipse areas, corresponding to the mean standard ellipse area and 95, 75 and 50\% confidence intervals in the 4 species studied

location where spawning occurred. The use of CSI$\mathrm{A}_{\mathrm{AA}}$, particularly for calculating TP, highlighted how this effect can lead to apparent, yet inaccurate, trophic differences in the early life of tunas when comparing only SIA $_{\text {bulk }}$ values. Lipid composition analysis and lipid reserves utilization has also revealed a capital breeding strategy in the congeneric albacore tuna $T$. alalunga from the Indian Ocean (Dhurmeea et al. 2018). Highest total lipids were found in the liver of albacore pre-spawners, which suggested they rely mostly on stored lipids for energy associated with reproduction (Dhurmeea et al. 2018).

Table 4. Percentage overlap of the maximum likelihood estimate of sample size corrected ellipse area values for postflexion larvae of 4 tuna species collected in the eastern Gulf of Mexico

\begin{tabular}{|lcccc|}
\hline Species & T. thynnus & T. atlanticus & A. rochei & K. pelamis \\
\hline Thunnus thynnus & - & 17.4 & 0.0 & 17.5 \\
T. atlanticus & 18.6 & - & 0.0 & 15.8 \\
Auxis rochei & 0.0 & 0.0 & - & 31.2 \\
Katsuwonus pelamis & 37.1 & 15.8 & 56.8 & - \\
\hline
\end{tabular}
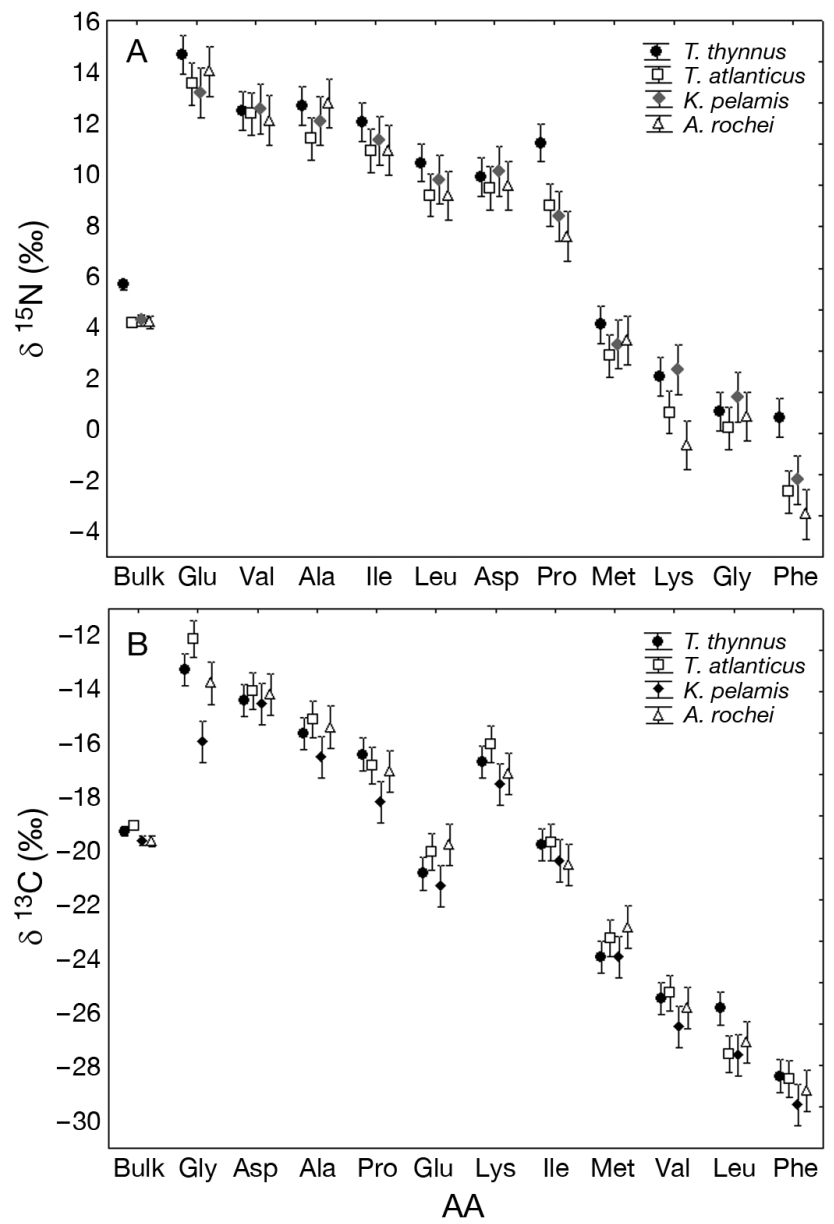

Fig. 7. (A) Nitrogen compound-specific stable isotopes of amino acids $\left(\mathrm{CSIA}_{\mathrm{AA}}\right)$ for Thunnus thynnus, T. atlanticus, Auxis rochei, and Katsuwonus pelamis from the Gulf of Mexico. Trophic amino acids (Glu, Val, Ala, Ile, Leu, Asp) and source amino acids (Met, Lys, Gly, Phe) are indicated. $\delta^{15} \mathrm{~N}_{\text {bulk }}$ has been plotted for reference. (B) Carbon CSIA $\mathrm{AA}_{\mathrm{A}}$ for tuna larvae. Non-essential amino acids (NEAA: Gly, Asp, Ala, Pro, Glu) and essential amino acids (EAA: Lys, Ile, Met, Val, Leu, Phe) are indicated. Lipid-corrected $\delta^{13} C_{\text {bulk }}$ has been plotted for reference

In this study, the 4 species of tunas ( $T$. thynnus, $T$. atlanticus, $K$. pelamis and A. rochei) were observed in the same region -in the waters of the Loop Current and its associated eddies-where potentially enhanced primary production occurs, and thus creates a more favorable feeding habitat, despite suggestions of spatial partitioning among members of Thunnini (Richardson et al. 2010, LindoAtichati et al. 2012, Muhling et al. 2013, Rooker et al. 2013, Cornic et al. 2018). Considering the similarities in their distributions, our stable isotope data revealed a degree of resource partitioning. 

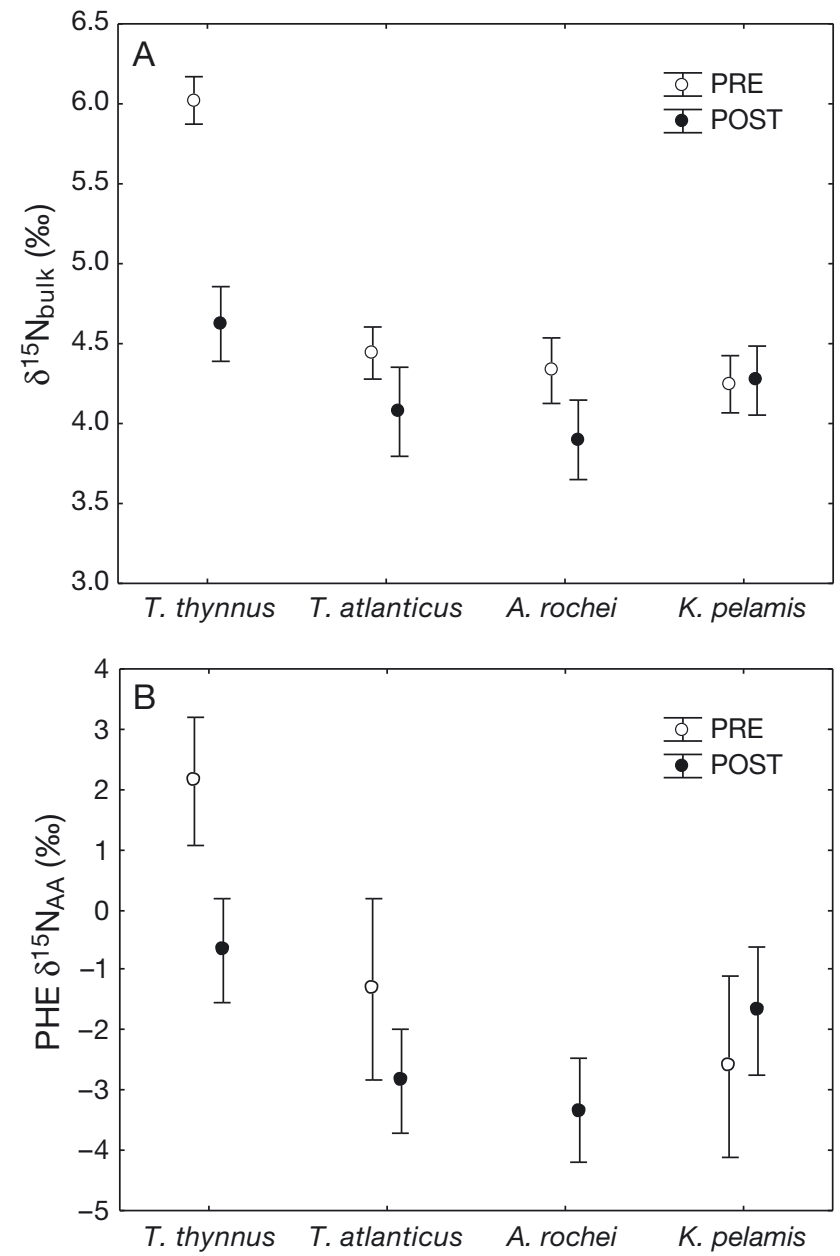

Fig. 8. Comparative preflexion and postflexion stage nitrogen isotopic signature for Thunnus thynnus, T. atlanticus, Auxis rochei, and Katsuwonus pelamis larvae from the Gulf of Mexico using both (A) bulk stable isotopes analysis $\left(\delta^{15} \mathrm{~N}_{\text {bulk }}\right)$, and (B) compound-specific stable isotope analysis of phenylalanine (PHE $\delta^{15} \mathrm{~N}_{\mathrm{AA}}$ )

Table 5. Trophic position (TP) estimates (mean \pm SE) for postflexion tuna larvae in Gulf of Mexico, applying 2 different accepted models for bulk nitrogen stable isotope $\left(\delta^{15} \mathrm{~N}_{\text {bulk }}\right)$ and nitrogen compound-specific stable isotopes of amino acids $\left(\delta^{15} \mathrm{~N}_{\mathrm{AA}}\right)$. Different letters next to the values indicate significant differences $(p<0.05)$ among species

\begin{tabular}{|c|c|c|}
\hline Species/group & $\mathrm{TP}_{\mathrm{Bulk}}{ }^{\mathrm{a}}$ & $\mathrm{TP}_{\mathrm{Glu} / \mathrm{Phe}}{ }^{\mathrm{b}}$ \\
\hline Thunnus thynnus & $2.76 \pm 0.06 a$ & $2.46 \pm 0.06$ \\
\hline T. atlanticus & $2.30 \pm 0.07 b$ & $2.72 \pm 0.12$ \\
\hline Katsuwonus pelamis & $2.41 \pm 0.05 b$ & $2.49 \pm 0.05$ \\
\hline Auxis rochei & $2.29 \pm 0.06 b$ & $2.84 \pm 0.04$ \\
\hline Zooplankton $^{\mathrm{C}}(40-500 \mu \mathrm{m})$ & 2.6 & \\
\hline \multicolumn{3}{|c|}{ 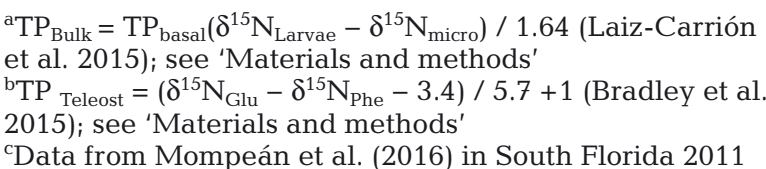 } \\
\hline
\end{tabular}

$\delta^{13} \mathrm{C}_{\text {bulk }}$ revealed differences in food sources for both Thunnus species compared to $K$. pelamis and $A$. rochei (Fig. 6). However, the CSIA $_{\mathrm{AA}}$ results revealed that the higher $\delta^{15} \mathrm{~N}_{\text {bulk }}$ values in T. thynnus were primarily due to differences in source AAs and not trophic position, as $\delta^{15} \mathrm{~N}_{\mathrm{AA}}$ values of source AAs (e.g. Phe) are higher in the T. thynnus postflexion larvae compared to the other 3 species (see Fig. 7). Therefore, caution is suggested with $\delta^{15} \mathrm{~N}_{\text {bulk }}$ results, because we cannot distinguish if a consumer's isotopic signature changes due to feeding interactions or variations in baseline isotopic signatures. Through CSIA $_{A A}$ we can resolve this shortcoming of SIA bulk analysis, as we (and others) have shown distinct potential in elucidating information about both nutrient sources and trophic interactions from a single organism (McClelland \& Montoya 2002, Popp et al. 2007, Chikaraishi et al. 2009, Hannides et al. 2009).

Most indicative of trophic niche separation were carbon isotopic signatures, as the 2 Thunnus species ( $T$. thynnus and T. atlanticus) had significantly higher $\delta^{13} \mathrm{C}_{\text {bulk }}$ values than the other 2 tuna species $(K$. pelamis and $A$. rochei) (Fig. 5). Since $\delta^{13} \mathrm{C}_{\text {bulk }}$ signatures of consumers are determined by the $\delta^{13} \mathrm{C}_{\text {bulk }}$ values of primary producers, lower $\delta^{13} \mathrm{C}_{\text {bulk }}$ values may suggest a greater oceanic contribution to carbon sources (France 1995, Takai et al. 2002, Tanaka et al. 2008, Laiz-Carrión et al. 2013, 2015). However, there was considerably greater variability in the $\delta^{13} \mathrm{C}$ values of $K$. pelamis and $A$. rochei, suggesting that these species utilize a broader range of carbon sources (Fry \& Sherr 1989, Fry 2002). Differences in $\delta^{13} C_{\text {bulk }}$ may stem from the documented differences in diets of these tunas, as K. pelamis and A. rochei are known to primarily consume appendicularians during their early stages (prior to becoming piscivorous), in contrast with the mixed but copepod-rich diet of $T$. atlanticus and T. thynnus (Llopiz et al. 2010, 2015). Appendicularians act as a short circuit of the microbial loop, and thereby may consume a broader range of carbon through their microbial consumption. This particular feeding mode may lead to regional variability of the carbon signature in appendicularians, and consequently their predators, as observed in this study (Azam et al. 1983, Jaspers et al. 2015). A second hypothesis for the differences in $\delta^{13} C_{\text {bulk }}$ range is the depth distribution of the larvae. Preliminary data indicate that $\delta^{13} \mathrm{C}_{\text {bulk }}$ of particulate organic matter in the GOM is significantly depleted at the deep chlorophyll maximum compared to surface waters. These differences open the possibility that species with greater larval vertical distribution can feed on deeper zooplankton resulting in lower $\delta^{13} \mathrm{C}_{\text {bulk }}$ val- 
ues, which may be the case for K. pelamis and Auxis spp. (Llopiz et al. 2010). Further investigation is needed to elucidate how the combination of both these hypotheses could explain differences in nutrient source utilization. Furthermore, $K$. pelamis showed the highest $\mathrm{SEA}_{\mathrm{B}}$ of the tuna larvae studied (Fig. 6B). This large isotopic niche may be explained by the earlier display of piscivorous feeding in $K$. pelamis (Uotani et al. 1981, Llopiz et al. 2010, Llopiz \& Hobday 2015, García et al. 2017). Particularly, the broad range of $\delta^{13} \mathrm{C}_{\text {bulk }}$ values in K. pelamis (Fig. 6A) could be explained by a mixture of piscivory and consumption of appendicularians, likely resulting in a broad range of carbon sources (Llopiz et al. 2010, Jaspers et al. 2015). This is substantiated by the broad range in $\delta^{13} \mathrm{C}_{\text {bulk }}$ values for $A$. rochei larvae, also a known consumer of appendicularians (Llopiz et al. 2010).

The estimations of the isotopic niche overlap (Fig. 6A) suggest some competition among the species in postflexion larvae, in which a trophic niche overlap was observed between $T$. thynnus, $T$. atlanticus and A. rochei with $K$. pelamis $(17.5,15.8$, and $31.2 \%$, respectively). The trophic niche of $T$. thynnus and T. atlanticus overlap (18.6 to $17.4 \%$ ) mainly due to similarities in $\delta^{13} \mathrm{C}_{\text {bulk }}$ values together with the differences $\delta^{15} \mathrm{~N}_{\text {bulk }}$ signatures, though this may be due to differences in baseline $\delta^{15} \mathrm{~N}_{\text {bulk }}$ utilization between species. The lack of overlap between A. rochei and $T$. thynnus suggests a higher trophic segregation. Diet data corroborate these differences, as A. rochei is primarily a consumer of appendicularians while $T$. thynnus has a mixed diet and attains piscivory at greater postflexion lengths (Llopiz et al. 2010), having shown a density-dependent cannibalistic behavior in the Mediterranean Sea (Uriarte et al. 2018, 2019).

Trophic position estimates using CSIA $_{\mathrm{AA}}$ (Bradley et al. 2015) indicated that $T$. thynnus TP $(2.47 \pm 0.06)$ was not significantly different from the other tunas. This contrasted with TP calculations based on SIA bulk which, due to higher $\delta^{15} \mathrm{~N}_{\text {bulk }}$ values in T. thynnus relative to the other 3 larval tuna species, led to a higher TP estimate for T. thynnus. Phe $\delta^{15} \mathrm{~N}_{\mathrm{AA}}$ values revealed differences in the source AA between $T$. thynnus and the other 3 species, and consequently the TP estimation based on $\delta^{15} \mathrm{~N}_{\text {bulk }}$ varied not only because of the trophic AA influence (Glu), but also due to differences in the source. We attribute these differences in TP estimation to discrepancies in $\delta^{15} \mathrm{~N}$ baseline utilization, as SIA $_{\text {bulk }}$ assume the same $\delta^{15} \mathrm{~N}$ baseline for 4 species (microzooplankton size fraction), whereas CSIA $_{\mathrm{AA}}$ reveals differences in the source values (Phe $\delta^{15} \mathrm{~N}_{\mathrm{AA}}$ ).
Similarly, ontogenetic differences in SIA $_{\text {bulk }}$ values between pre- and postflexion tuna larvae are likely a result of maternal transmission of isotopes (Uriarte et al. 2016). $\Delta{ }^{15} \mathrm{~N}_{\text {bulk }}$ values of $T$. thynnus during the early larval stage were higher than those of tuna species at the same stage. We applied the maternal isotopic transmission model to these preflexion larvae to estimate maternal isotopic signatures (Uriarte et al. 2016) and found the $\mathrm{N}$ isotopic values estimated $($ mean \pm SD: $12.11 \pm 1.83 \%$ ) were similar to those reported for adult $T$. thynnus in the GOM spawning area (approx. 11 to 13\%; see Butler et al. 2015, Logan et al. 2011). Uriarte et al. (2016) demonstrated under food-controlled experimental conditions that maternal signatures of $T$. thynnus were transmitted to the early larval stage, then gradually decreased during ontogenetic development until reaching a steady state with food sources after the postflexion stage. This hypothesis demonstrates the preflexion isotopic signatures close to adult fishes thereby reflecting the larval food sources in the spawning area.

Applying this reasoning, the SIA $\mathrm{Aulk}_{\text {bifferences be- }}$ tween pre- and postflexion $T$. thynnus larvae in our results could be the result of 2 causes: adult T. thynnus breeders are feeding at a higher trophic level and/or that $T$. thynnus is a capital breeder and its gametes incorporate a baseline isotopic signature from another region (i.e. foraging area) that differs from the baseline signature of the GOM. Information on the lipid dynamics involved in reproduction suggests a capital breeding strategy for T. thynnus (Mourente et al. 2001), and this hypothesis is also supported by our results obtained for CSIA $_{A A}$, which showed significantly higher $\delta^{15} \mathrm{~N}_{\mathrm{AA}}$ values in the source AA Phe for preflexion larvae than postflexion larvae, and higher than those of other species at the same stage. These results agree with the isotopic signatures previously reported for $T$. thynnus larvae and co-occurring tuna species on the Balearic Sea spawning grounds (NW Mediterranean: T. alalunga, A. rochei, and Euthynnus alletteratus) (García et al. 2017). Although results from stomach contents and lipid content analyses on T. thynnus support active feeding during the spawning season in GOM, primarily upon gelatinous zooplankton, cephalopods, and low-lipid teleosts, their energetic demands are unlikely to be fully met and the reproductive potential is formed prior to this sustained feeding during spawning (Butler et al. 2015). For the 3 other species of tunas in the GOM, our results suggest the adults obtained the energy necessary for reproduction in the same region they are spawning. However, our results by themselves cannot be used to distinguish an income breeding strategy from that of a 
non-migrating capital breeder. Grande et al. (2016) suggested an income breeding strategy for K. pelamis. Although no information is available for the T. atlanticus breeding strategy, a tagging study in the GOM showed evidence of subpopulations and minimal migratory patterns (Luckhurst et al. 2001). We know that A. rochei are non-migratory, and are income breeders in the Mediterranean (Alemany et al. 2010); it is reasonable assume that this species also exerts an income breeding strategy in the GOM. Further comparative research on reproductive energetics is clearly necessary but, in accordance with Tanaka et al. (2016) and Mei et al. (2018), our results suggest that SIA of larvae could be a potential tool to infer information on the type of breeding strategy.

The relationship between breeder and larval isotope signatures of each tuna species should be studied further by combining the analysis of isotope signatures of larval fishes and potential food sources in the natural environment. Although ontogenetic and diet rearing experiments have been performed for some tuna larvae (Miyashita et al. 2001, Tanaka et al. 2010, 2014, Reglero et al. 2014, Uriarte et al. 2016), as well as analyses of isotope signatures in the field (Laiz-Carrión et al. 2013, 2015, García et al. 2017), further experiments with aquaculture-reared tuna larvae are required to interpret and calibrate with field observations.

In summary, the present study used 2 independent stable isotope analyses, SIA and CSIA $_{\mathrm{AA}}$, to elucidate early life trophic interactions among co-inhabiting tunas through determining their trophic niche and the overlap of their trophic niches. The $\delta^{15} \mathrm{~N}_{\text {bulk }}$ and $\delta^{13} \mathrm{C}_{\text {bulk }}$ values were significantly different, indicating resource partitioning among species, where $K$. pelamis showed the greatest trophic niche overlap with the 3 other species. Conversely, both congeneric species, T. thynnus and T. atlanticus, showed the least overlap, indicating different feeding strategies between these species.

In addition, the transgenerational transmission of maternal signatures to preflexion stages recommends their segregation in further isotopic studies on larval trophodynamics. Lastly, the maternal isotopic signatures imprinted in preflexion tuna larvae through the confluence of SIA and CSIA AA $_{\text {techniques opens }}$ new research perspectives that may reveal trophicrelated information with respect to the breeding strategies of spawners.

Acknowledgements. This work was largely supported by ATAME CTM2011-29525-C04-02 and ECOLATUN CTM201568473-R (MINECO/FEDER) projects funded by the Spanish
Ministry of Economy and Competitiveness. A.U. was a recipient of a predoctoral fellowship FPI-IEO 2011/03 (Spanish Institute of Oceanography). J.J.S. was partially supported by the US National Science Foundation (OCE1536782). J.K.L. was supported by the Woods Hole Oceanographic Institution (WHOI)'s Ocean Life Institute, WHOI's Penzance Endowed Support for Assistant Scientists, and NOAA through the Cooperative Institute for the North Atlantic Region (CINAR) under Cooperative Agreement NA14OAR4320158 in the form a CINAR Fellow Award. Finally, the authors thank the NOAA Fisheries Oceanography for Recruitment, Climate and Ecosystem Studies Unit, the staff at the Polish Plankton Sorting and Identification Center in Szczecin, Poland, the crew of the R/V 'F. G. Walton Smith', and the Southeast Area Monitoring and Assessment Program. This research was partially funded by NASA (NNX11AP76G), NOAA National Marine Fisheries Science Service \& Southeast Fisheries Science Center, as well as by the Cooperative Institute for Marine and Atmospheric Studies (NA15OAR43200064).

\section{LITERATURE CITED}

Alemany F, Quintanilla L, Velez-Belchi P, García A and others (2010) Characterization of the spawning habitat of Atlantic bluefin tuna and related species in the Balearic Sea (western Mediterranean). Prog Oceanogr 86:21-38

Azam F, Fenchel T, Field JG, Gray JS, Meyer-Reil LA, Thingstad F (1983) The ecological role of water-column microbes in the sea. Mar Ecol Prog Ser 10:257-263

Bakun A (1996) Patterns in the ocean: ocean processes and marine population dynamics. California Sea Grant, in cooperation with Centro de Investigaciones Biologicas del Noroeste, La Paz

Bakun A (2006) Fronts and eddies as key structures in the habitat of marine fish larvae: opportunity, adaptive response and competitive advantage. Sci Mar 70(Suppl 2):105-122

Bakun A (2013) Ocean eddies, predator pits and bluefin tuna: implications of an inferred 'low risk-limited payoff' reproductive scheme of a (former) archetypical top predator. Fish Fish 14:424-438

*Bakun A, Broad K (2003) Environmental loopholes and fish population dynamics: comparative pattern recognition with particular focus on El Niño effects in the Pacific. Fish Oceanogr 12:458-473

Batschelet E (1981) Circular statistics in biology. Academic Press, London

Block BA, Stevens ED (eds) (2001) Tuna: physiology, ecology, and evolution. Fish physiology, Vol 19. Academic Press, San Diego, CA

Block BA, Dewar H, Blackwell SB, Williams TD and others (2001) Migratory movements, depth preferences, and thermal biology of Atlantic bluefin tuna. Science 293: 1310-1314

Block BA, Teo SLH, Walli A, Boustany A and others (2005) Electronic tagging and population structure of Atlantic bluefin tuna. Nature 434:1121-1127

* Bode A, Alvarez-Ossorio MT, Cunha ME, Garrido S and others (2007) Stable nitrogen isotope studies of the pelagic food web on the Atlantic shelf of the Iberian Peninsula. Prog Oceanogr 74:115-131

Boecklen WJ, Yarnes CT, Cook BA, James AC (2011) On the use of stable isotopes in trophic ecology. Annu Rev Ecol Syst 42:411-440 
Bradley CJ, Wallsgrove NJ, Choy CA, Drazen JC, Hetherington ED, Hoen DK, Popp BN (2015) Trophic position estimates of marine teleosts using amino acid compound specific isotopic analysis. Limnol Oceanogr Methods 13: 476-493

Butler CM, Logan JM, Provaznik JM, Hoffmayer ER (2015) Atlantic bluefin tuna Thunnus thynnus feeding ecology in the northern Gulf of Mexico: a preliminary description of diet from the western Atlantic spawning grounds. J Fish Biol 86:365-374

Catalán IA, Tejedor A, Alemany F, Reglero P (2011) Trophic ecology of Atlantic bluefin tuna Thunnus thynnus larvae. J Fish Biol 78:1545-1560

* Chikaraishi Y, Ogawa NO, Kashiyama Y, Takano Y and others (2009) Determination of aquatic food-web structure based on compound-specific nitrogen isotopic composition of amino acids. Limnol Oceanogr Methods 7: $740-750$

Coll M, Palomera I, Tudela S, Sarda F (2006) Trophic flows, ecosystem structure and fishing impacts in the South Catalan Sea, northwestern Mediterranean. J Mar Syst 59:63-96

* Cornic M, Rooker JR (2018) Influence of oceanographic conditions on the distribution and abundance of blackfin tuna (Thunnus atlanticus) larvae in the Gulf of Mexico. Fish Res 201:1-10

* Cornic M, Smith BL, Kitchens L, Alvarado Bremer JR, Rooker JR (2018) Abundance and habitat associations of tuna larvae in the surface water of the Gulf of Mexico. Hydrobiologia 806:29-46

Davies CA, Gosling EM, Was A, Brophy D, Tysklind N (2011) Microsatellite analysis of albacore tuna (Thunnus alalunga): population genetic structure in the north-east Atlantic Ocean and Mediterranean Sea. Mar Biol 158: 2727-2740

De Metrio G, Arnold GP, Block BA, de la Serna JM and others (2002) Behaviour of post-spawning Atlantic bluefin tuna tagged with pop-up satellite tags in the Mediterranean and Eastern Atlantic. Col Vol Sci Pap ICCAT 54: 415-424

Nohurmeea Z, Pethybridge H, Appadoo C, Bodin N (2018) Lipid and fatty acid dynamics in mature female albacore tuna (Thunnus alalunga) in the Western Indian Ocean. PLOS ONE 13:e0194558

Domingues R, Goni G, Bringas F, Muhling B, Lindo-Atichati D, Walter J (2016) Variability of preferred environmental conditions for Atlantic bluefin tuna (Thunnus thynnus) larvae in the Gulf of Mexico during 1993-2011. Fish Oceanogr 25:320-336

Fantle MS, Dittel AI, Schwalm SM, Epifanio CE, Fogel ML (1999) A food web analysis of the juvenile blue crab, Callinectes sapidus, using stable isotopes in whole animals and individual amino acids. Oecologia 120:416-426

Fogel ML, Tuross N (2003) Extending the limits of paleodietary studies of humans with compound specific carbon isotope analysis of amino acids. J Archaeol Sci 30: 535-545

France RL (1995) Carbon-13 enrichment in benthic compared to planktonic algae: foodweb implications. Mar Ecol Prog Ser 124:307-312

Fromentin JM, Fonteneau A (2001) Fishing effects and life history traits: a case-study comparing tropical versus temperate tunas. Fish Res 53:133-150

Fry B (2002) Stable isotope indicators of habitat use by Mississippi River fish. J North Am Benthol Soc 21:676-685
Fry B, Sherr EB (1989) $\delta^{13} \mathrm{C}$ measurements as indicators of carbon flow in marine and freshwater ecosystems. In: Rundel PW, Ehleringer JR, Nagy KA (eds) Stable isotopes in ecological research. Springer-Verlag, New York, NY, p 196-229

García A, Cortes D, Ramírez T, Fehri-Bedui R and others (2006) First data on growth and nucleic acid and protein content of field captured Mediterranean bluefin (T. thynnus) and albacore (T. alalunga) larvae: a comparative study. Sci Mar 70:67-78

García A, Laiz-Carrión R, Uriarte A, Quintanilla JM and others (2017) Differentiated stable isotopes signatures between pre- and post-flexion larvae of Atlantic bluefin tuna (Thunnus thynnus) and of its associated tuna species of the Balearic Sea (NW Mediterranean). Deep Sea Res II 140:18-24

* Grande M, Murua H, Zudaire I, Arsenault-Pernet EJ, Pernet F, Bodin N (2016) Energy allocation strategy of skipjack tuna Katsuwonus pelamis during their reproductive cycle. J Fish Biol 89:2434-2448

*Hannides CCS, Popp BN, Landry MR, Graham BS (2009) Quantification of zooplankton trophic position in the North Pacific Subtropical Gyre using stable nitrogen isotopes. Limnol Oceanogr 54:50-61

*Hare JA (2014) The future of fisheries oceanography lies in the pursuit of multiple hypotheses. ICES J Mar Sci 71: 2343-2356

Houde ED (1987) Fish early life dynamics and recruitment variability. Am Fish Soc Symp 2:17-29

* Jackson AL, Inger R, Parnell AC, Bearhop S (2011) Comparing isotopic niche widths among and within communities: SIBER — stable isotope Bayesian ellipses in R. J Anim Ecol 80:595-602

Jackson MC, Donohue I, Jackson AL, Britton JR, Harper DM, Grey J (2012) Population-level metrics of trophic structure based on stable isotopes and their application to invasion ecology. PLOS ONE 7:e31757

Jaspers C, Acuña JL, Brodeur RD (2015) Interactions of gelatinous zooplankton within marine food webs. J Plankton Res 37:985-988

Kodama T, Hirai J, Tamura S, Takahashi T and others (2017) Diet composition and feeding habits of larval Pacific bluefin tuna Thunnus orientalis in the Sea of Japan: integrated morphological and metagenetic analysis. Mar Ecol Prog Ser 583:211-226

Kaiz-Carrión R, Quintanilla JM, Torres AP, Alemany F, García A (2013) Hydrographic patterns conditioning variable trophic pathways and early life dynamics of bullet tuna Auxis rochei larvae in the Balearic Sea. Mar Ecol Prog Ser 475:203-212

*aiz-Carrión R, Gerard T, Uriarte A, Malca E and others (2015) Trophic ecology of Atlantic bluefin tuna (Thunnus thynnus) larvae from the Gulf of Mexico and NW Mediterranean spawning grounds: a comparative stable isotope study. PLOS ONE 10:e0138638

Lamkin, JT, Muhling BA, Malca E, Laiz-Carrión R and others (2014) Do western Atlantic bluefin tuna spawn outside of the Gulf of Mexico? Results from a larval survey in the Atlantic Ocean. Col Vol Sci Pap ICCAT 71: 1736-1745

Lindo-Atichati D, Bringas F, Goni G, Muhling B, MullerKarger FE, Habtes S (2012) Variability of mesoscale structures with effects on larval fish distribution in the northern Gulf of Mexico during spring month. Mar Ecol Prog Ser 463:245-257 
Llopiz JK, Hobday AJ (2015) A global comparative analysis of the feeding dynamics and environmental conditions of larval tunas, mackerels, and billfishes. Deep Sea Res II 113:113-124

Llopiz JK, Richardson DE, Shiroza A, Smith SL, Cowen RK (2010) Distinctions in the diets and distributions of larval tunas and the important role of appendicularians. Limnol Oceanogr 55:983-996

Llopiz JK, Muhling BA, Lamkin JT (2015) Feeding dynamics of Atlantic bluefin tuna (Thunnus thynnus) larvae in the Gulf of Mexico. Col Vol Sci Pap ICCAT 71:1710-1715

* Logan JM, Jardine TD, Miller TJ, Bunn SE, Cunjak RA, Lutcavage ME (2008) Lipid corrections in carbon and nitrogen stable isotope analyses: comparison of chemical extraction and modelling methods. J Anim Ecol 77: 838-846

* Logan JM, Rodríguez-Marín E, Goñi N, Barreiro S, Arrizabalaga H, Golet W, Lutcavage M (2011) Diet of young Atlantic bluefin tuna (Thunnus thynnus) in eastern and western Atlantic foraging grounds. Mar Biol 158:73-85

Luckhurst BE, Trott T, Manuel S (2001) Landings, seasonality, catch per unit effort, and tag-recapture results of yellowfin and blackfin tuna at Bermuda. Am Fish Soc Symp 25:225-234

Lutcavage ME, Brill RW, Skomal GB, Chase BC, Howey PW (1999) Results of pop up satellite tagging of spawning size class fish in the Gulf of Maine: Do North Atlantic bluefin tuna spawn in the mid-Atlantic? Can J Fish Aquat Sci 56:173-177

Martínez del Rio C, Wolf N, Carleton SA, Gannes LZ (2009) Isotopic ecology ten years after a call for more laboratory experiments. Biol Rev Camb Philos Soc 84:91-111

McBride RS, Somarakis S, Fitzhugh GR, Albert A and others (2015) Energy acquisition and allocation to egg production in relation to fish reproductive strategies. Fish Fish 16:23-57

McClelland JW, Montoya JP (2002) Trophic relationships and the nitrogen isotopic composition of amino acids in plankton. Ecology 83:2173-2180

McMahon KW, Fogel ML, Elsdon TS, Thorrold SR (2010) Carbon isotope fractionation of amino acids in fish muscle reflects biosynthesis and isotopic routing from dietary protein. J Anim Ecol 79:1132-1141

McMahon KW, Hamadi LL, Thorrold SR (2013) A review of ecogeochemistry approaches to estimating movements of marine animals. Limnol Oceanogr 58:697-714

* McMahon KW, Thorrold SR, Elsdon TS, McCarthy MD (2015) Trophic discrimination of nitrogen stable isotopes in amino acids varies with diet quality in a marine fish. Limnol Oceanogr 62:1076-1087

Mei W, Umezawa Y, Wan X, Yuan J, Sassa C (2018) Feeding habits estimated from weight-related isotope variations of mesopelagic fish larvae in the Kuroshio waters of the northeastern East China Sea. ICES J Mar Sci fsy016

Miyashita S, Sawada Y, Okada T, Murata O, Kumai H (2001) Morphological development and growth of laboratoryreared larval and juvenile Thunnus orientalis (Pisces: Scombridae). Fish Bull 99:601-616

Mompeán C, Bode A, Latasa M, Fernández-Castro B, Mouriño-Carballido B, Irigoien X (2016) The influence of nitrogen inputs on biomass and trophic structure of ocean plankton: a study using biomass and stable isotope size-spectra. J Plankton Res 38:1163-1177

Moncreiff CA, Sullivan MJ (2001) Trophic importance of epiphytic algae in subtropical seagrass beds: evidence from multiple stable isotope analysis. Mar Ecol Prog Ser 215:93-106

* Mourente G, Megina C, Díaz-Salvago E (2001) Lipids in female northern bluefin tuna (Thunnus thynnus thynnus L.) during sexual maturation. Fish Physiol Biochem 24: 351-363

* Muhling BA, Lamkin JT, Quattro JM, Smith RH and others (2011) Collection of larval bluefin tuna (Thunnus thynnus) outside documented western Atlantic spawning grounds. Bull Mar Sci 87:687-694

*Muhling BA, Reglero P, Ciannelli L, Alvarez-Berastegui D and others (2013) Comparison between environmental characteristics of larval bluefin tuna Thunnus thynnus habitat in the Gulf of Mexico and western Mediterranean Sea. Mar Ecol Prog Ser 486:257-276

*Muhling BA, Lamkin JT, Alemany F, García A and others (2017) Reproduction and larval biology in tunas, and the importance of restricted area spawning grounds. Rev Fish Biol Fish 27:697-732

*Nakagawa Y, Eguchi M, Miyashita S (2007) Pacific bluefin tuna, Thunnus orientalis, larvae utilize energy and nutrients of microbial loop. Aquaculture 267:83-93

* Olson RJ, Popp BN, Graham BS, López-Ibarra GA and others (2010) Food web inferences of stable isotope spatial patterns in copepods and yellowfin tuna in the pelagic eastern Pacific Ocean. Prog Oceanogr 86:124-138

* Peterson BJ, Fry B (1987) Stable isotopes in ecosystem studies. Annu Rev Ecol Syst 18:293-320

* Pinnegar JK, Polunin NVC (1999) Differential fractionation of $\delta^{13} \mathrm{C}$ and $\delta^{15} \mathrm{~N}$ among fish tissues: implications for the study of trophic interactions. Funct Ecol 13:225-231

*Polis G, Strong DR (1996) Food web complexity and community dynamics. Am Nat 147:813-846

* Popp BN, Graham BS, Olson RJ, Hannides CC and others (2007) Insight into the trophic ecology of yellowfin tuna, Thunnus albacares, from compound-specific nitrogen isotope analysis of proteinaceous amino acids. Terr Ecol $1: 173-190$

* Post DM (2002) Using stable isotopes to estimate trophic position: models, methods and assumptions. Ecology 83: 703-718

R Development Core Team (2012) R: a language and environment for statistical computing. R Foundation for Statistical Computing, Vienna

* Reglero P, Tittensor DP, Álvarez-Berastegui D, AparicioGonzález A, Worm B (2014) Worldwide distributions of tuna larvae: revisiting hypotheses on environmental requirements for spawning habitats. Mar Ecol Prog Ser 501:207-224

Richards WJ (1977) A further note on Atlantic bluefin tuna spawning. Col Vol Sci Pap ICCAT 6:335-336

Richards WJ, Potthoff Y (1980) Distribution and abundance of bluefin tuna larvae in the Gulf of Mexico in 1977 and 1978. Col Vol Sci Pap ICCAT 9:433-441

* Richardson DE, Llopiz JK, Guigand CM, Cowen RK (2010) Larval assemblages of large and medium-sized pelagic species in the Straits of Florida. Prog Oceanogr 86:8-20

* Richardson DE, Marancik KE, Guyon JR, Lutcavage ME and others (2016) Discovery of a spawning ground reveals diverse migration strategies in Atlantic bluefin tuna (Thunnus thynnus). Proc Natl Acad Sci USA 113: 3299-3304

* Ricklefs RE, Nealen P (1998) Lineage-dependent rates of evolutionary diversification: analysis of bivariate ellipses. Funct Ecol 12:871-885 
Rooker JR, Bremer AJR, Block BA, Dewar H and others (2007) Life history and stock structure of Atlantic bluefin tuna (Thunnus thynnus). Rev Fish Sci 15:265-310

Rooker JR, Kitchens LL, Dance MA, Wells RJD and others (2013) Spatial, temporal, and habitat-related variation in abundance of pelagic fishes in the Gulf of Mexico: potential implications of the Deepwater Horizon oil spill. PLOS ONE 8:e76080

Stephens PA, Boyd IL, McNamara JM, Houston AI (2009) Capital breeding and income breeding: their meaning, measurement, and worth. Ecology 90:2057-2067

Suca JJ, Llopiz JK (2017) Trophic ecology of barrelfish (Hyperoglyphe perciformis) in oceanic waters of southeast Florida. Bull Mar Sci 93:987-996

Suca JJ, Pringle JW, Knorek ZR, Hamilton SL, Richardson DE, Llopiz JK (2018) Feeding dynamics of Northwest Atlantic small pelagic fishes. Prog Oceanogr 165:52-62

Takai N, Mishima Y, Yorozu A, Hoshika A (2002) Carbon sources for demersal fish in the western Seto Inland Sea, Japan, examined by $\delta^{13} \mathrm{C}$ and $\delta^{15} \mathrm{~N}$ analyses. Limnol Oceanogr 47:730-741

Tanaka H, Takasuka A, Aoki I, Ohshimo S (2008) Geographical variations in the trophic ecology of Japanese anchovy, Engraulis japonicus, inferred from carbon and nitrogen stable isotope ratios. Mar Biol 154:557-568

Tanaka Y, Minami H, Ishihi Y, Kumon K and others (2010) Prey utilization by hatchery-reared Pacific bluefin tuna larvae in mass culture tank estimated using stable isotope analysis, with special reference to their growth variation. Aquac Sci 58:501-508

Tanaka Y, Minami H, Ishihi Y, Kumon K and others (2014) Relationship between prey utilization and growth variation in hatchery-reared Pacific bluefin tuna, Thunnus orientalis (Temminck et Schlegel), larvae estimated using nitrogen stable isotope analysis. Aquac Res 45:537-545

Tanaka H, Yoneda M, Kitano H, Kawamura K and others (2016) Stable isotope evidence for income resource allocation to egg production in the Japanese anchovy Engraulis japonicus. Mar Biol 163:28-33

Teo SLH, Block BA (2010) Comparative influence of ocean

Editorial responsibility: Stylianos Somarakis,

Heraklion, Greece conditions on yellowfin and Atlantic bluefin tuna catch from longlines in the Gulf of Mexico. PLOS ONE 5: e10756

Teo SLH, Boustany A, Block BA (2007) Oceanographic preferences of Atlantic bluefin tuna, Thunnus thynnus, on their Gulf of Mexico breeding grounds. Mar Biol 152: 1105-1119

*Tilley JD, Butler CM, Suárez-Morales E, Franks JS and others (2016) Feeding ecology of larval Atlantic bluefin tuna, Thunnus thynnus, from the central Gulf of Mexico. Bull Mar Sci 92:321-334

*Uotani I, Matsuzaki K, Makino Y, Noda K and others (1981) Food habits of larvae of tunas and their related species in the area northwest of Australia. Bull Jpn Soc Sci Fish 47: 1165-1172

* Uriarte A, García A, Ortega A, de La Gándara F, Quintanilla JM, Laiz-Carrión R (2016) Isotopic discrimination factors and nitrogen turnover rates in reared Atlantic bluefin tuna larvae (Thunnus thynnus): effects of maternal transmission. Sci Mar 80:447-456

Uriarte A, Johnstone C, Laiz-Carrión R, García A and others (2018) First report on cannibalistic feeding behaviour in post-flexion bluefin larvae (Thunnus thynnus) of the Balearic Sea (NW Mediterranean) Col Vol Sci Pap ICCAT 74:2554-2562

* Uriarte A, Johnstone C, Laiz-Carrión R, García A and others (2019) Evidence of density-dependent cannibalism in the diet of wild Atlantic bluefin tuna larvae (Thunnus thynnus) of the Balearic Sea (NW Mediterranean). Fish Res 212:63-71

*Vander Zanden MJ, Rasmussn JB (2001) Variation in $\delta^{15} \mathrm{~N}$ and $\delta^{13} \mathrm{C}$ trophic fractionation: implications for aquatic food web. Limnol Oceanogr 46:2061-2066

* Varela JL, Larrañaga A, Medina A (2011) Prey-muscle carbon and nitrogen stable-isotope discrimination factors in Atlantic bluefin tuna (Thunnus thynnus). J Exp Mar Biol Ecol 406:21-28

*Walsh RG, He S, Yarnes CT (2014) Compound-specific $\delta^{13} \mathrm{C}$ and $\delta^{15} \mathrm{~N}$ analysis of amino acids: a rapid, chloroformatebased method for ecological studies. Rapid Commun Mass Spectrom 28:96-108

Submitted: June 11, 2018; Accepted: April 4, 2019

Proofs received from author(s): May 18, 2019 